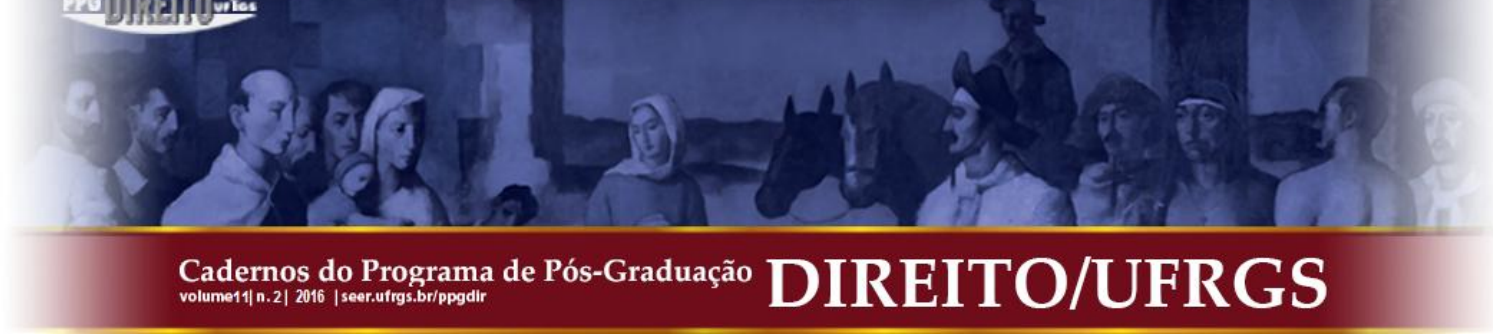

\title{
O DIREITO DO TRABALHO NO PÓS-POSITIVISMO: UMA NOVA PERSPECTIVA SOBRE UM VELHO DIREITO SOCIAL
}

\author{
LABOUR LAW IN POSTPOSITIVISM: A NEW PERSPECTIVE ABOUT AN OLD SOCIAL \\ RIGHT
}

Antonio Braga da Silva Junior*

\begin{abstract}
RESUMO: O Direito do Trabalho, por tratar de valor central na ordem constitucional brasileira - o trabalho humano digno -, carece de uma repaginação para o intérprete, de modo a evoluir o paradigma positivista em que foi idealizada a Consolidação das Leis do Trabalho. A teoria positivista do Direito, embasadora da opção político-ideológica liberal do século XIX e, mais recentemente, do neoliberalismo, mostra-se incapaz de promover a contento a efetividade dos direitos fundamentais trabalhistas na atual ordem democrático-constitucional. Desponta, daí, o clamor por uma reanálise das normas trabalhistas. O Direito do Trabalho póspositivista, ao enxergar os valores sociais e princípios tutelares do labor como parte integrante do núcleo constitucional irradiador de efeitos para toda a ordem jurídica, apresenta-se à atividade jurídica e política do Estado e até mesmo às relações particulares como instrumento essencial para a realização do projeto constitucional de afirmação da dignidade da pessoa humana, de democratização da tutela social e de alcance da justiça social.
\end{abstract}

PALAVRAS-CHAVE: Direito do Trabalho. Pós-positivismo. Constitucionalismo. Estado Democrático de Direito.
ABSTRACT: The Labour Law, since it addresses a central value to the Brazilian constitutional order - decent human labor -, needs to be redesigned in the eyes of the interpreter, in order to overcome the positivist paradigm in which the Consolidation of Labor Laws was designed. The positivist theory of law, which has based the liberal politics of the nineteenth century and, more recently, the neoliberalism, seems unable to promote the effectiveness of labor fundamental rights in a satisfactory manner at the current democratic and constitutional order. Therefore, the necessity of a re-examination of labor law arises. The post-positivist Labor Law, by considering the principles and social values of human labor as part of the constitutional core that irradiates effects throughout the whole legal system, presents itself to the judicial and the policymaking state activities and even to private relations as an essential instrument for the realization of the constitutional project of human dignity affirmation, of social protection democratization and of achieving social justice.

KEYWORDS: Labor law. Postpositivism. Constitutionalism. Democratic State of Law

SUMÁRIO: Introdução; 1 A superação do positivismo jurídico. 2 O pós-positivismo como novo paradigma jusfilosófico. 2.1 A abertura axiológica do sistema jurídico. 2.2 A normatividade dos princípios. 2.3. A constitucionalização do Direito. 2.4 Direitos Fundamentais centrados na dignidade da pessoa humana. $3 \mathrm{O}$ direito do trabalho pós-positivista. $3.1 \mathrm{O}$ movimento pendular da história constitucional do Direito do Trabalho em face das transformações socioeconômicas. 3.2 A renovação juslaboral: o Direito do Trabalho no constitucionalismo democrático brasileiro. 3.3 O Direito do Trabalho no contexto pós-positivista. Considerações Finais. Referências.

\section{INTRODUÇÃO}

Como bem se percebe atualmente, são cada vez mais crescentes as investidas patronais a favor de flexibilizações das regras protecionistas do Direito do Trabalho, o intenso lobby para ampliação da terceirização de serviços, as propostas extremistas de total desregulamentação trabalhista inspiradas, por exemplo, na dura realidade da China ou dos Tigres Asiáticos.

Essas propostas patronais - que na atualidade ganham ainda mais força com o momento de crise socioeconômica nacional - fundamentam-se numa revisitação do ideário liberalindividualista predominante no já longínquo início do século XX, que, por sua vez, enxergava

\footnotetext{
* Mestrando em Direito no Instituto Brasiliense de Direito Público (IDP). Auditor-Fiscal do Trabalho.
} 


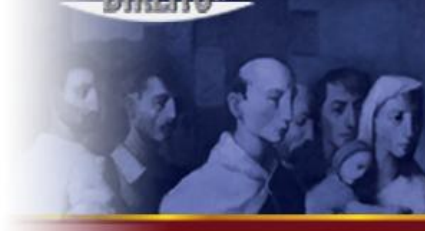

na lógica formal, neutra e avalorativa do positivismo jurídico uma ferramenta eficaz para o atingimento dos seus objetivos patrimonialistas.

O alicerce juspositivista em que fora idealizada a Consolidação das Leis do Trabalho principal diploma legal regulador das relações de trabalho, editado ainda em 1943 - , portanto, talvez seja capaz de explicar os percalços e investidas atualmente presenciadas contra a proteção do trabalho hipossuficiente.

Entretanto, o contexto social e político mudou. Da mesma forma, a teoria do Direito evoluiu. Os valores exaltados pela sociedade são outros, e, agora, mais evidentes. A rígida estrutura jurídica positivista, alheia à realidade empírica e a qualquer conteúdo axiológico, apresenta-se atualmente insustentável, impotente que se mostra para compreender a realidade jurídica de uma sociedade crescentemente complexa e plural.

A atual ordem democrático-constitucional, repleta de exaltação de valores e princípios tutelares do labor humano, em uma nítida vocação antropocêntrica ${ }^{1}$ centrada na dignidade da pessoa humana, passa, então, a questionar a aptidão do modelo justrabalhista tradicional para promover a contento a efetividade dos direitos fundamentais trabalhistas.

Diante desse contexto, desponta o objetivo central deste estudo: a reanálise do Direito do Trabalho pelo prisma constitucional, a partir dos referenciais filosófico-jurídicos do póspositivismo.

Em uma tomada de postura crítica sobre o tema, sem qualquer pretensão de se propor elaboração de uma teoria crítica, foi utilizado como método de desenvolvimento do trabalho a construção de uma digressão sobre o pós-positivismo por meio de uma bibliografia de referência no campo teórico-filosófico do Direito. Assentadas as premissas teóricas fundamentais, foram em seguida apresentados os parâmetros retóricos circulantes na doutrina

\footnotetext{
1 "Vocação antropocêntrica" da Constituição da República é uma expressão emprestada do voto do Ministro Relator Luis Felipe Salomão no paradigmático caso conhecido como Chacina da Candelária no âmbito do Superior Tribunal de Justiça - STJ, em que fora discutida a concorrência entre liberdade de imprensa (interesse público de divulgação midiática do caso) em contraponto ao direito ao esquecimento (direito da personalidade de um dos envolvidos de não ter seu nome vinculado ao crime noticiado em rede nacional). Na ocasião, o STJ decidiu por unanimidade a prevalência do direito ao esquecimento, assentando como um dos fundamentos da decisão que os diversos dispositivos constitucionais tutelares da intimidade, honra, imagem e demais valores da pessoa e da família evidenciam uma predileção constitucional para soluções protetivas da pessoa humana. Concluiu, portanto, que "a despeito de a informação livre de censura ter sido inserida no seleto grupo dos direitos fundamentais (art. $5^{\circ}$, inciso IX), a Constituição Federal mostrou sua vocação antropocêntrica no momento em que gravou, já na porta de entrada (art. $1^{\circ}$, inciso III), a dignidade da pessoa humana como - mais que um direito - um fundamento da República, uma lente pela qual devem ser interpretados os demais direitos posteriormente reconhecidos". BRASIL. Superior Tribunal de Justiça. Recurso Especial n ${ }^{\circ}$ 1.334.097-RJ (2012/0144910-7). Min. Rel. Luis Felipe Salomão, julgado em 28/05/13, publicado DJe em 10/09/2013. Disponível em <http://www.stj.jus.br/SCON/>. Acesso em 28/11/15.
} 


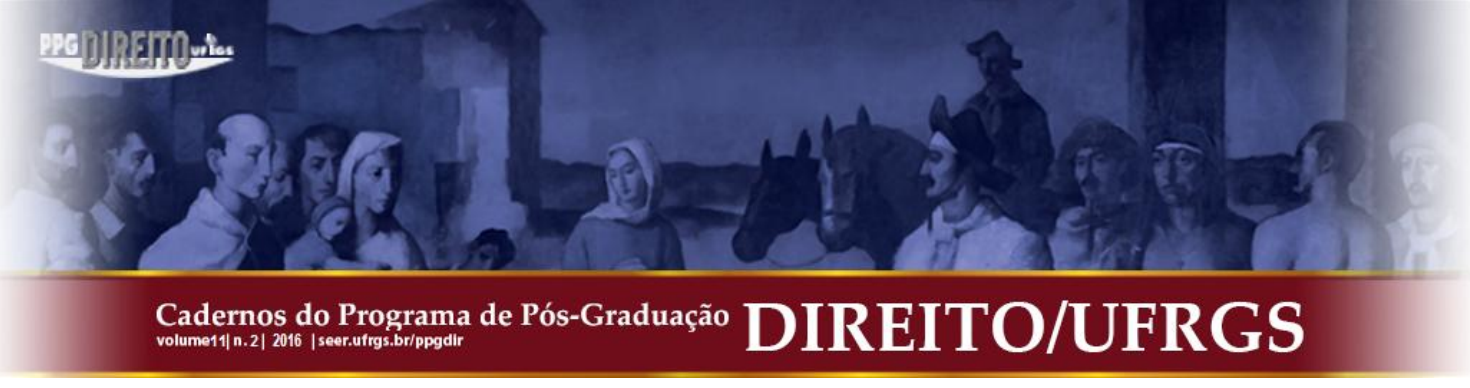

hegemônica juslaboral e apontados os elementos paradigmáticos da superação da visão formalista do direito na seara trabalhista, com o fim de se desenvolver reflexões diferenciadas e transformadoras sobre a realidade juslaboral.

Para atingir o objetivo proposto, o presente artigo foi estruturado em duas partes. A primeira, em um viés jusfilosófico generalista, tratará da superação do positivismo jurídico, haja vista sua antiquada rigidez formal e acrítica. Consecutivamente à impotência do positivismo, analisar-se-á o advento do pós-positivismo como novo paradigma jusfilosófico, caracterizado pela comunicação do ordenamento jurídico aos valores pulsantes na sociedade, pela normatividade dos princípios tal como das regras, pelo foco na Constituição como fonte das normas fundamentais e pela consolidação dos direitos fundamentais centrados na dignidade da pessoa humana, que mudam a face do Direito para atender aos clamores por justiça social e valorização humana no novo século.

A segunda parte do trabalho, em um recorte trabalhista do tema, enfocará a necessária repaginação do Direito do Trabalho pela perspectiva jusfilosófica pós-positivista. A análise se dará com a observação evolutiva dos fatores econômicos, sociais e políticos ao longo da história juslaboral, demonstrando que, quando vigente o momento político-ideológico Liberal, o Direito do Trabalho via-se oprimido diante da tendência civilista individual-patrimonialista calcada no positivismo tradicional; quando passado ao Estado de Bem-Estar Social, o Direito do Trabalho iniciava sua fase de fortalecimento a ponto de constitucionalizar-se mundo afora. E atualmente, no contexto do Estado democrático constitucional, mesmo diante de ameaçadoras investidas neoliberais, o Direito do Trabalho tem na perspectiva pós-positivista uma promissora proposta, como se verá adiante.

\section{A SUPERAÇÃO DO POSITIVISMO JURÍDICO}

A filosofia juspositivista, que doravante chamaremos de positivismo tradicional ${ }^{2}$, funda-se no positivismo científico, em que inclusive as ciências sociais são tidas como conhecimento científico objetivo, neutro, livre de juízos de valor e de ideologias, livre de indagações

\footnotetext{
${ }^{2}$ Bem se sabe que o positivismo jurídico não representa uma unidade homogênea. Ao contrário, várias foram as "versões" de positivismos ao longo da história, tal como as clássicas idealizações de Hans Kelsen, Alf Ross, H.L.A Hart, Norberto Bobbio e Joseph Raz. Entretanto, para fins didáticos e para facilitar a explanação, trataremos por "positivismo tradicional" a estrutura lógica central caraterizadora dessa corrente de pensamento, conformadora de uma identidade teórica a despeito das diversas nuances criadas circunstancialmente.
} 


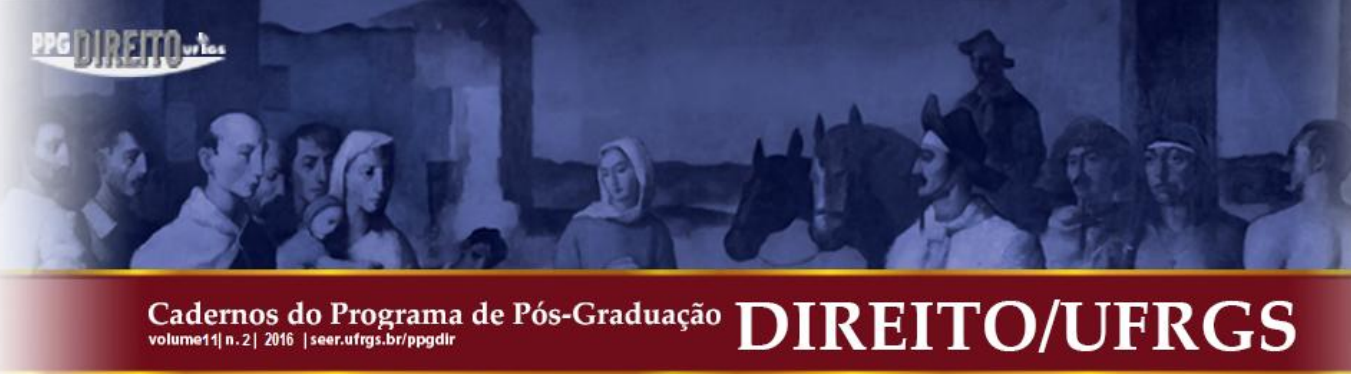

metafísicas. Essa importação da teoria científico-positivista para o âmbito jurídico fez como que o direito fosse concebido de modo apartado à moral e aos valores transcendentes. A pretensa ciência jurídica se fundava, então, distanciada de questões como legitimidade e justiça. ${ }^{3}$

O sistema jurídico era pensado estritamente em sua estrutura lógico-formal. E esse pensamento cartesiano se justificava pelo contexto da transição histórica para a fase moderna, em que a partir do século XVIII a sociedade clamava por imposição de limites ao poder arbitrário e ilimitado do soberano. Mostrava-se necessário enclausurar o sistema jurídico contra os valores jusnaturalista, que sustentavam os desmandos absolutistas com fundamentos vagos e metafísicos de uma razão subjetiva. Minguava-se, daí, a preocupação com o conteúdo moral diante da premente necessidade de se conformar o sistema jurídico.

Em busca dessa segurança jurídica e objetividade do sistema jurídico, o juspositivismo é concebido, portanto, como ciência da legislação positiva, que pressupõe uma situação histórica concreta: a concretização da produção jurídica em uma única instância constitucional, a instância legislativa. Seu significado supõe uma redução de todo o sistema jurídico ao texto da lei, nela incluindo os direitos e a justiça, de modo que a atividade do jurista se resumiria simplesmente em perscrutar a vontade clara do legislador. ${ }^{4}$

É nesse cenário que se solidifica a doutrina do positivismo jurídico, capitaneada pela teoria kelseniana. Para Hans Kelsen, em sua Teoria Pura do Direito - cuja própria denominação denota o estudo do Direito alheio a valores e a quaisquer outras interferências epistemológicas (filosofia, economia, sociologia) -, o direito se limitava ao aspecto da validade formal da lei, independentemente de seu conteúdo. Mesmo com a idealização da norma fundamental como fundamento de validade para o ordenamento jurídico, essa norma fundamental era pensada por Kelsen como mero pressuposto lógico-formal de validade do Direito, sem exercer qualquer função ético-política relacionada à fundamentação do conteúdo do Direito. 5

\footnotetext{
${ }^{3}$ BARROSO, Luís Roberto. Fundamentos teóricos e filosóficos do novo direito constitucional brasileiro (pósmodernidade, teoria crítica e pós-positivismo). In: BARROSO, Luís Roberto (org.). A nova interpretação constitucional: ponderação, direitos fundamentais e relações privadas. 3. ed. revista. Rio de Janeiro: Renovar, 2008, p. 1-48. p. 23.

${ }^{4}$ ZAGREBELSKY, Gustavo. El derecho dúctil. Traducción de Marina Gascón. $7^{\text {a }}$ ed. Madrid: Trotta, 2007. p. 33.

${ }^{5}$ KELSEN, Hans. Capítulo V - Dinâmica Jurídica. In: ___ . Teoria pura do Direito. Tradução de João Baptista Machado. $6^{\text {a }}$ ed. São Paulo: Martins Fontes, 1999. p. 135-194.
}

\section{7}




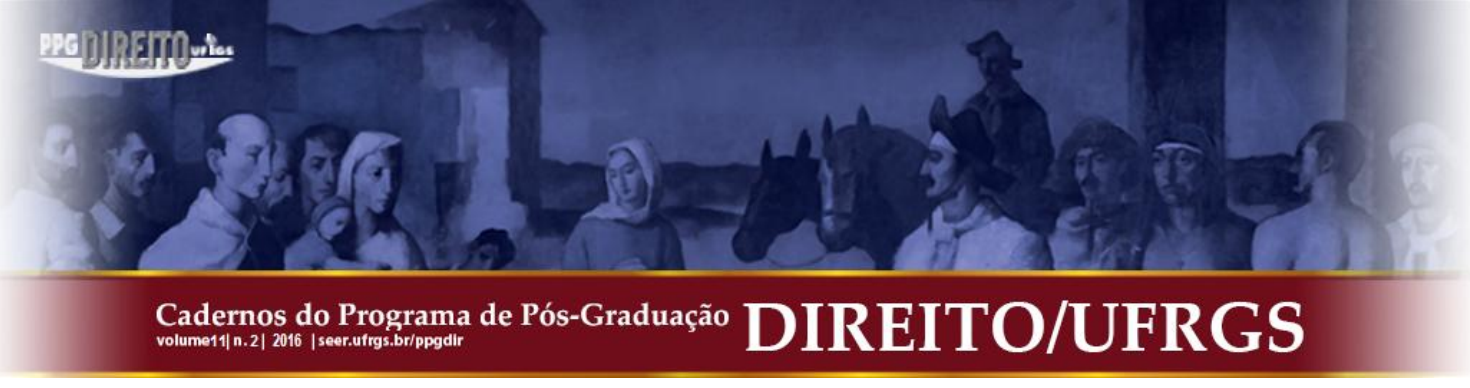

Malgrado o inestimável legado epistemológico do positivismo tradicional, é fato que a visão de distanciamento entre valores e normas jurídicas criou um verdadeiro abismo entre as dimensões do ser e o dever ser. Diante da concepção do ordenamento jurídico edificado sobre os critérios de validade formal das normas, com tendência anti-ideológica, o Direito na concepção juspositivista abria-se a indistintas espécies de conteúdo.

A disseminação do positivismo jurídico, em que o Direito era traduzido como um conjunto de normas em vigor compondo um sistema perfeito e prescindível de qualquer justificação moral além da própria validade, tornou-se inclusive terreno fértil para a legitimação de doutrinas autoritaristas responsáveis por lamentáveis resquícios históricos da humanidade. Nas palavras de Luís Roberto Barroso:

O fetiche da lei e o legalismo acrítico, subprodutos do positivismo jurídico, serviram de disfarce para autoritarismos de matizes variados. A ideia de que o debate acerca da justiça se encerrava quando da positivação da norma tinha um caráter legitimador da ordem estabelecida. Qualquer ordem. ${ }^{6}$

Além da legitimação de regimes totalitaristas, o juspositivismo, diante da sua rigidez racional, acrítica, igualmente não se mostrava capaz de encontrar soluções perante as cada vez mais complexas relações da plural sociedade moderna. Passa a ser crescente a evidência da insuficiência da norma posta para, em casos sensíveis, limítrofes e nebulosos, promover e garantir a justiça social.

O próprio Hans Kelsen, quando tem o capítulo A Interpretação de sua citada obra Teoria Pura do Direito analisado em pormenor, já nos sinaliza, ainda que sutilmente, algumas limitações do positivismo tradicional. ${ }^{7}$ Com efeito, diz o autor que o ato de interpretação jurídica submete-se a "uma relativa indeterminação". Isso porque "A norma do escalão superior não pode [não é capaz de] vincular em todas as direções (sob todos os aspectos) o ato através do qual é aplicada. Tem sempre de ficar uma margem, ora maior ora menor, de livre apreciação". Acrescenta que "Mesmo uma ordem o mais pormenorizada possível tem de deixar àquele que a cumpre ou executa uma pluralidade de determinações a fazer", haja vista

\footnotetext{
${ }^{6}$ BARROSO, Luís Roberto. Fundamentos teóricos e filosóficos do novo direito constitucional brasileiro (pósmodernidade, teoria crítica e pós-positivismo). In: (org.). A nova interpretação constitucional: ponderação, direitos fundamentais e relações privadas. 3. ed. revista. Rio de Janeiro: Renovar, 2008, p. 1-48. p. 22-23.

${ }^{7}$ KELSEN, Hans. Capítulo VIII - A Interpretação. In: Teoria pura do Direito. Tradução de João Baptista Machado. $6^{\text {a }}$ ed. São Paulo: Martins Fontes, 1999. p. 245-251.
} 


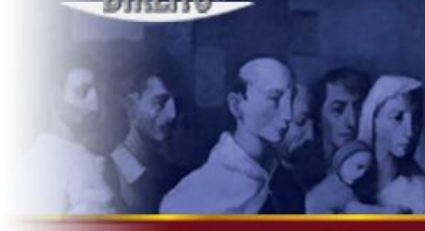

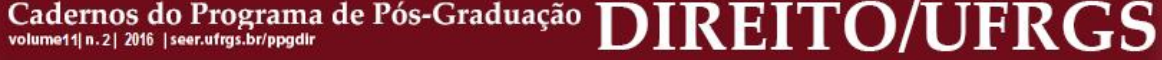

a dependência de "circunstâncias externas que o órgão emissor do comando não previu e, em grande parte, nem sequer podia prever". 8

Kelsen deixa transparecer, portanto, sua conclusão no sentido da limitação do positivismo jurídico para antever todas as plúrimas e complexas circunstâncias sociais sobre as quais recai o Direito. E, para contornar essa limitação latente, assume - a nosso ver de modo contraditório ao seu intento positivista de segurança jurídica - que "Sendo assim, a interpretação de uma lei não deve necessariamente conduzir a uma única solução como sendo a única correta, mas possivelmente a várias soluções que - na medida em que sejam aferidas pela lei a aplicar - têm igual valor"”. Descortina-se na análise do próprio Kelsen, portanto, as primeiras evidências de impotência do positivismo jurídico.

De acordo com a análise de Luis Prieto Sanchís, a decadência do positivismo tradicional vem na verdade de um fenômeno quantitativo: a multiplicação das normas pela complexidade da sociedade moderna e o aumento da intervenção do Estado nos problemas sociais. Esse fenômeno de multiplicação legal no fim provoca um fenômeno qualitativo: as decisões dos juízes e demais operadores do Direito passam a uma intervenção circunstancial e casuística. A multiplicação das leis, a complexidade e variedade de casos sociais enfrentados e a velocidade de mutação fizeram com que certeza das leis se tornasse insegurança. ${ }^{10}$

A impotência do positivismo jurídico, portanto, abriu caminho para profundas reflexões acerca do Direito, bem como da sua função social e sua interpretação. A ferramenta lógicodedutiva antes utilizada para a solução de conflitos passou a denotar sua insuficiência diante de casos difíceis, de obscuridades e de conflito de normas para o caso concreto. As intensas críticas instigaram os doutrinadores a adaptar suas teorias e concepções às necessidades complexas enfrentadas no mundo jurídico.

Diante da desvelada crise do positivismo tradicional, os teóricos da filosofia jurídica passam a concebê-lo com a necessidade de relativização do parâmetro de validade exclusivamente formal da norma. O positivismo exclusivo ${ }^{11}$ (duro, inflexível) passa à

\footnotetext{
${ }^{8}$ Idem. Ibidem. p. 246.

${ }^{9}$ Idem. Ibidem. p. 247.

${ }^{10}$ SANCHÍS, Luis Prieto. Del mito a la decadencia de la Ley: la Ley en el estado constitucional. In: Ley, principios, derechos. Madrid: Dykinson, 1998. p. 5-45. p. 22-23.

${ }^{11} \mathrm{De}$ acordo com a vertente positivista apelidada de exclusiva (ou dura, inflexível), que possui de Joseph Raz como principal nome, a norma jurídica é identificada como válida por referência exclusivamente às suas fontes formais, independentemente do seu conteúdo moral. Para a diferenciação entre as vertentes exclusiva e inclusiva do positivismo, vide DIMOULIS, Dimitri. Positivismo jurídico: introdução a uma teoria do direito e defesa do pragmatismo jurídico-político. São Paulo: Método, 2006. p. 134-136.
} 


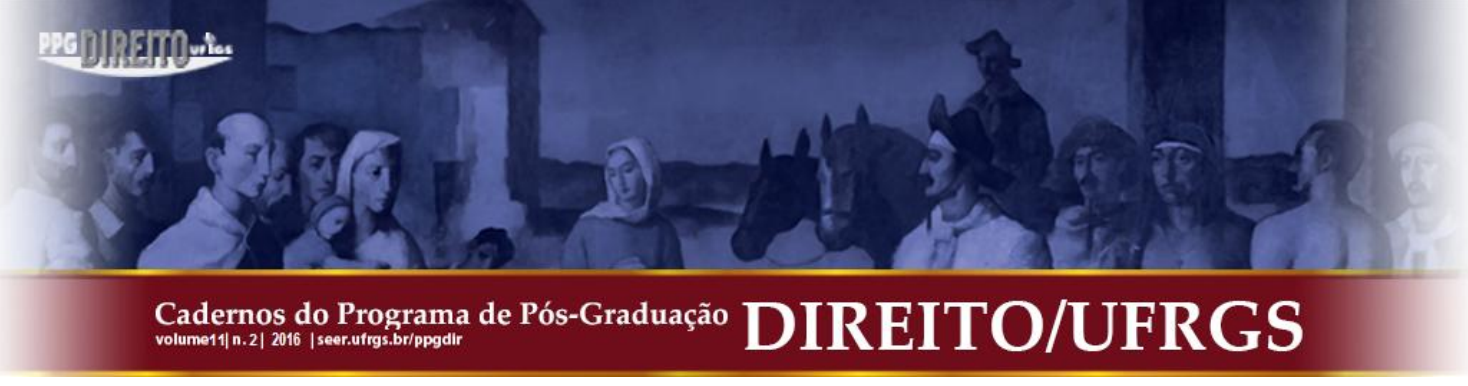

adaptação, recebendo conformação de uma nova nuance positivista, de nítida aproximação do sistema jurídico ao sistema moral, batizada de positivismo inclusivo, ou moderado, tendo H.L.A. Hart como principal representante ${ }^{12}$, mormente após o elucidativo posfácio de sua obra $O$ conceito de Direito ${ }^{13}$.

Notável, nesse cenário, a busca de aproximação do Direito com a moral - sem, contudo, confundi-los. A história mundial não mais aceitaria que arbitrariedades e tiranias fossem legitimadas pelo Direito. Necessário se mostrava uma análise crítica do conteúdo das normas do ordenamento jurídico, com parâmetros morais de justiça. Surgia, daí, o caminho para uma nova etapa da teoria do Direito: o pós-positivismo jurídico.

\section{O PÓS-POSITIVISMO COMO NOVO PARADIGMA JUSFILOSÓFICO}

Após profundos traumas históricos decorrentes de regimes totalitários e de duas guerras avassaladoras, o Direito já não poderia ser acusado de ser uma mera racionalidade instrumental destinada à satisfação dos interesses das classes dominantes.

Efervesceram mundo afora discussões acerca da necessária observância pelo sistema jurídico dos valores enaltecidos pela sociedade. Surgiram, principalmente a partir da segunda metade do século XX, inovações filosóficas e jurídicas que se inspiraram na nova ordem social, calcada principalmente na dignidade do ser humano e na justiça social.

Diante da evolução social, o Direito carecia de uma reanálise. Tornava-se cada vez mais evidente a obsolescência da perspectiva estritamente formal do Direito, alheia a juízos éticos e à realidade empírica. ${ }^{14} \mathrm{O}$ mundo prático torna-se importante. As questões sociais, políticas e econômicas, antes isoladas pelo positivismo, passam agora a instigar os debates dos juristas.

\footnotetext{
${ }^{12}$ A construção teórica da regra de reconhecimento de Hart, que em cada comunidade estabelece os critérios de validade jurídica a partir da aceitação social, rechaça a noção tradicional positivista de que Direito é exclusivamente o legislado. A grande contribuição de Hart é valorizar a fonte social do Direito, exaltando outros elementos no Direito que não apenas o sistema formal lógico-dedutivo (tal como em Kelsen e Ross).

${ }^{13}$ HART, Herbert Lionel Adolphus. O Conceito de Direito. $3^{\text {a }}$ edição. Tradução de A. Ribeiro Mendes. Lisboa: Fundação Calouste Gulbekian, 1994. No posfácio dessa obra, Hart busca responder as críticas geradas pela primeira edição de seu livro, principalmente as críticas "de grande alcance" de Ronald Dworkin.

${ }^{14}$ A título de exemplo, relembremos o artigo 402 da Consolidação das Leis do Trabalho - CLT, que, em sua redação original de 1943, admitia o trabalho do menor de 18 (dezoito) anos, sem qualquer limitação, em trabalhos sob direção do pátrio poder, como medida de educação infantil. No momento histórico em que editado, a absoluta exaltação do pátrio poder sobre os interesses da criança justificavam a medida - o que por óbvio se mostra atualmente inimaginável diante do hodierno aparato de proteção psicossocial das crianças e adolescentes. Atualmente o artigo 402 apresenta-se completamente reeditado, em consonância com a proteção do trabalho do menor estatuído no artigo $7^{\circ}$, XXXIII da Constituição da República, nas Convenções n. ${ }^{\circ} 138$ e 182 da
} 


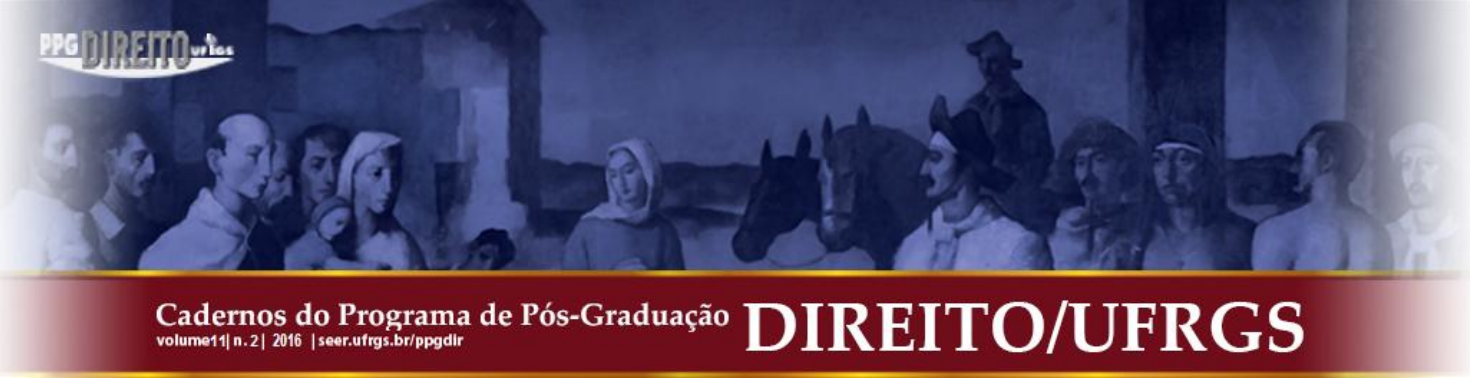

$\mathrm{O}$ valor absoluto da lei torna-se relativizado diante das contingências humanas. $\mathrm{O}$ legado científico do positivismo jurídico clamava por um olhar crítico, mais penetrante. Tal como uma estrutura sintática de uma língua que não se mostra útil sem a respectiva semântica e observância das necessidades pragmáticas, as importantes conquistas formais positivistas suscitavam preenchimento de conteúdo.

Em busca de uma nova racionalidade jurídica, prospectiva, o objetivo passa a ser pensar o Direito para além da norma posta. É o que Karl Larenz categoricamente denominou de busca por um "direito extra legem, porém, intra jus". 15

Está-se, pois, diante do que veio a ser denominado pós-positivismo, marcado pelo intuito de preservação do legado positivista (legalidade e segurança jurídica), sem, todavia, se fechar à realidade social, política e econômica e aos valores pulsantes na sociedade.

Conforme observa Daniel Sarmento, a tendência pós-positivista do Direito pretende-se mais flexível e adaptável às contingências pós-modernas do que o direito coercitivo e sancionatório. Em profunda síntese, aduz o autor que "O direito pós-moderno é refratário à abstração conceitual e à axiomatização: prefere o concreto ao abstrato, o pragmático ao teórico, e rejeita as grandes categorias conceituais do Direito moderno". ${ }^{16}$

Em busca do imperioso desafio de se conformar interesses e se buscar justiça em uma sociedade complexa em sua pluralidade, notam-se as marcas dessa nova tendência jusfilosófica para o Direito: abertura do ordenamento jurídico aos valores sociais, normatividade dos princípios tal como das regras, o foco na Constituição como fonte das normas fundamentais e a consolidação dos direitos fundamentais centrados na dignidade da pessoa humana.

\subsection{A Abertura Axiológica do Sistema Jurídico}

Para se observar a relação entre valores e o Direito, necessário inicialmente a busca pelo significado de valor.

Organização Internacional do Trabalho - OIT e no Capítulo V da Lei n. ${ }^{\circ}$ 8.069/90 (Estatuto da Criança e do Adolescente).

${ }^{15}$ LARENZ, Karl. Metodologia da Ciência do Direito. Tradução de José Lamego. $3^{\text {a }}$ ed. Lisboa: Fundação Calouste Gulbenkian, 1997. p. 588.

${ }^{16}$ SARMENTO, Daniel Os direitos fundamentais nos paradigmas liberal, social e pós-social (Pós-Modernidade Constitucional?). In: SAMPAIO, José Adércio Leite (Coord.). Crise e desafios da Constituição: perspectivas críticas da teoria e das práticas constitucionais brasileiras. Belo Horizonte: Del Rey, 2003. p. 408-409. 


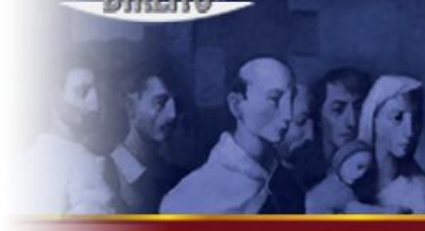

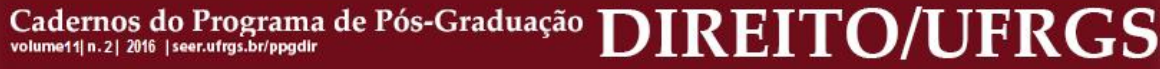

sistema e os transportam para a concretização do Direito, os valores, ao passo que garantem unidade ao ordenamento, figuram como pauta de atuação para o intérprete. ${ }^{20}$

\subsection{A Normatividade dos Princípios}

Para que o Direito se adaptasse a essa guinada da evolução social e não se tornasse alheio à sociedade que visa nortear, tampouco alheio aos valores nela impregnados, a teoria do Direito passa a exaltar a normatividade dos princípios, que, doravante, passariam a compor o sistema normativo, ao lado das regras.

Imperioso frisar que a grande novidade do pós-positivismo não estava propriamente na existência de princípios, ou no reconhecimento destes pelo ordenamento jurídico. Muito antes, mesmo na era jusnaturalista, em obras filosóficas ou religiosas já se observavam mandamentos principiológicos que influenciavam ainda que indiretamente o Direito. Tomese como exemplos o mandamento judaico-cristão de amor ao próximo, que inspira as relações humanas inclusive na atualidade, o fundamento grego da não-contradição, de Aristóteles, que embasa a não tolerância de antinomias pelo Direito, e, ainda, o brocardo romano de Ulpiano, que sintetizava os princípios básicos do Direito: "Viver com honestidade, não lesar o próximo e dar a cada um o que é seu". 21

A grande novidade reside, sim, no reconhecimento da normatividade dos princípios, em superação à concepção estritamente axiológica.

O assentamento da normatividade dos princípios ganha relevo para a Teoria do Direito principalmente com a doutrina de Ronald Dworkin ${ }^{22}$ e Robert Alexy ${ }^{23}$. Apesar das

sua concreção. In: LARENZ, Karl. Metodologia da Ciência do Direito. Tradução de José Lamego. $3^{\text {a }}$ ed. Lisboa: Fundação Calouste Gulbenkian, 1997. p. 406-413.

${ }^{20}$ BARROSO, Luís Roberto. Fundamentos teóricos e filosóficos do novo direito constitucional brasileiro (pósmodernidade, teoria crítica e pós-positivismo). In: BARROSO, Luís Roberto (org.). A nova interpretação constitucional: ponderação, direitos fundamentais e relações privadas. 3. ed. revista. Rio de Janeiro: Renovar, 2008, p. 1-48. p. 25.

${ }^{21}$ Idem. Ibidem. p. 24-25.

${ }^{22}$ No tocante à normatividade dos princípios, apesar das lições antecedentes de grande contribuição - como Esser e Larenz e suas distinções iniciais entre princípios e regras -, foi com Dworkin que o atual debate tomou força significativa, tendo como marco principal o seu artigo The Model of Rules (O modelo de regras), de 1967, e posteriormente sua famosa obra Taking Rights Seriously (Levando os direitos a sério). Uma das principais contribuições de Dworkin foi a noção de princípios como normas vinculativas e coercitivas. Segundo o autor, em uma comunidade de princípios o sistema jurídico não é encarado da mesma forma como ocorre em uma comunidade baseada em códigos. Em busca de um significado mais profundo além daquele expresso no texto da lei, a comunidade de princípios trata o ordenamento jurídico como uma decorrência do compromisso da 


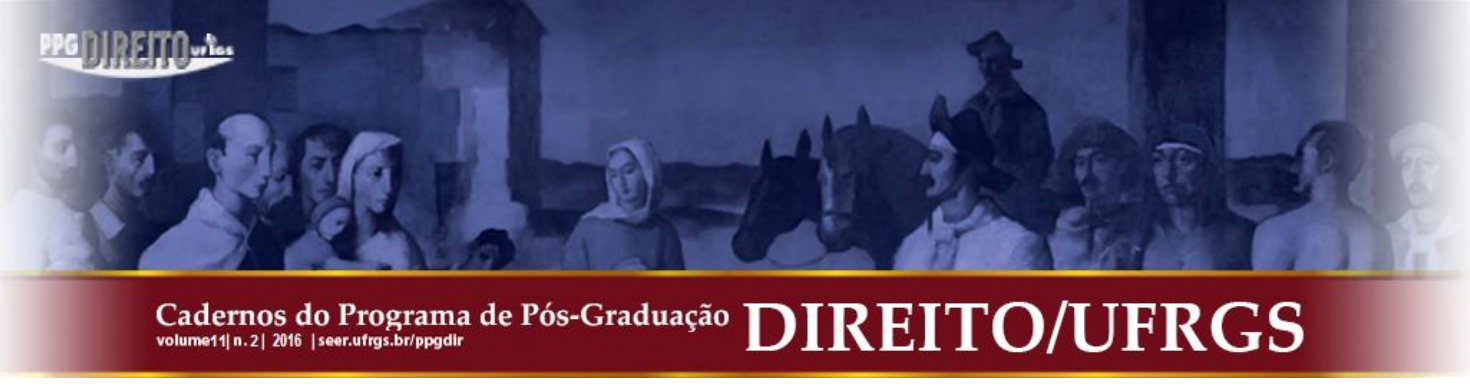

discrepâncias entre os autores quanto à definição de princípio e sua diferenciação de regras que em razão do enfoque deste artigo deixaremos de abordar -, ambas as concepções exaltam o caráter fluido dos princípios como ferramenta essencial para a superação da lógica do "tudo ou nada" na resolução de antinomias, capaz de mensurar o que de mais justo pode ser colhido da integralidade do sistema jurídico para a aplicação prática em cada caso trazido à discussão, em busca de justiça. Essa nova doutrina, portanto, consolida o caráter normativo dos princípios, que passam a se apresentar como fundamento de toda a ordem jurídica.

De acordo com preciosa síntese de Bonavides, a teoria dos princípios alcança a fase do pós-positivismo com resultados bem consolidados, mormente a passagem dos princípios da mera especulação metafísica para o campo concreto e positivo do Direito, o que acarretou a perda do caráter de meras normas programáticas e o reconhecimento de sua concretude no próprio texto constitucional. ${ }^{24}$

Tendo como ponto de partida uma Constituição que absorveu os princípios, o póspositivismo propõe-se à tarefa de fazer com que tais princípios tenham efetividade, quer mediante aplicabilidade imediata, quer, ainda, por invocação na resolução dos conflitos em casos concretos. A proposta pós-positivista é, pois, que os princípios deixem de ser meras reflexões filosóficas, ultrapassando a fronteira do idealismo para que assim possam assumir o embasamento de todo o sistema jurídico.

\subsection{A Constitucionalização do Direito}

Antes relegada a mera carta política de intenções, com minguada efetividade normativa, a Constituição, a partir da ótica jusfilosófica pós-positivista, passa a ser compreendida como sede natural de valores e princípios que ilumina todo o ordenamento jurídico. O contexto de acentuada importância conferida aos valores sociais e a normatividade dos princípios jurídicos

comunidade com o esquema precedente da moral política. DWORKIN, Ronald. $O$ império do direito. $2^{\mathrm{a}}$ ed. Tradução Jefferson Luiz Camargo. São Paulo: Martins Fontes, 2007.

${ }^{23} \mathrm{~A}$ doutrina alemã de Robert Alexy é festejada na atualidade mormente em razão dos estudos sobre a absorção e afirmação dos princípios no ordenamento jurídico contemporâneo, culminando com a constitucionalização na forma de direitos fundamentais - assunto tratado com maestria em sua obra Teoria dos Direitos Fundamentais. Como consecução do pensamento de Dworkin, a principal contribuição de Alexy para a doutrina moderna cingese à concepção de princípios como "mandados de otimização" (unindo a diferenciação dworkiana entre argumentos de princípios e argumentos de política), que inclusive inspirou teorias modernas sobre os direitos sociais, como mínimo existencial e vedação ao retrocesso social.

${ }^{24}$ BONAVIDES, Paulo. Curso de Direito Constitucional. $29^{\mathrm{a}}$ ed. São Paulo: Malheiros, 2014. 


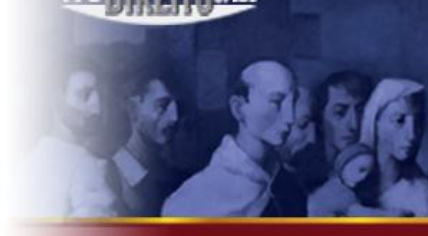

Cadernos do Programa de Pós-Graduação DIREITO/UFRGS

favoreceu a edificação dessa nova fase do Direito, que, por ter a Constituição como centro de organização política e de irradiação normativa, foi batizada de constitucionalismo ${ }^{25}$.

A célebre frase do constitucionalista Paulo Bonavides, "Ontem os códigos, hoje as Constituições"26, ilustra com propriedade o ponto de inflexão que o Direito de meados do século XX enfrentou. Se antes reinava a hegemonia do pensamento civilista, com sua forte característica liberal, individualista e patrimonialista calcada na filosofia juspositivista, o constitucionalismo passa a assumir o protagonismo, firmando-se de forma crescente como referência axiológica e normativa a todo o sistema jurídico, com potencialidade de transformar a sociedade. ${ }^{27}$

De acordo com a análise de Luis Prieto Sanchís, o novo constitucionalismo como Estado de Direito (forma de organização política imputável ao Estado de Direito) é o resultado da convergência de duas tradições constitucionais: o liberalismo típico da tradição norte americana, traduzido na limitação do poder político em prol dos valores individualistas, e o constitucionalismo social europeu, com origens ainda na Revolução Francesa, permeado por programas de transformação social e política que envolvia um amplo catálogo de direitos e de princípios não restrito a normas formais e procedimentais. Da primeira dessas tradições, mais liberal do que democrática, o constitucionalismo moderno herdou a ideia de garantia jurisdicional associada a uma desconfiança do legislador, de modo a se criar limites às deliberações deste - tal como o é o controle de constitucionalidade das leis. Da segunda

\footnotetext{
${ }^{25}$ Apesar da difundida opção terminológica "neoconstitucionalismo", preferimos neste trabalho a expressão "constitucionalismo". Isso porque, de acordo com Manuel Atienza, o polivalente termo "neoconstitucionalismo" está envolto de ambiguidades e imprecisões. Às vezes referem-no como fenômeno havido nos sistemas jurídicos modernos, de mudança do direito positivo e consequente centralização constitucional; outras vezes, como teoria do Direito apta à conceituação desse fenômeno. Ora utilizam o termo restrito ao Direito Constitucional, ora com amplitude referente ao ordenamento jurídico como um todo. E, como se não bastasse, o prefixo "neo" vem para aumentar a confusão, já que até onde se sabe não houve fenômeno ou teoria jurídica anterior que tenha se chamado de "constitucionalista" para justificar tal prefixo. In: ATIENZA, Manuel. Ni positivismo jurídico ni neoconstitucionalismo: una defensa del constitucionalismo postpositivista. Observatório da Jurisdição Constitucional. Ano 7, no 2, jul./dez. 2014. p. 02. Não é outra a opinião de Luis Prieto Sanchís, quem, diante das imprecisões terminológicas e dos diferentes usos do termo "neoconstitucionalismo", refere-se a essa "nova cultura jurídica" pelo termo "constitucionalismo". In: SANCHÍS, Luis Prieto. Sobre el neoconstitucionalismo y sus implicaciones. In: Justicia Constitucional y Derechos Fundamentales. Madrid: Trotta; 2003, p. 101.

${ }^{26}$ A breve porém profunda frase foi proferida por Paulo Bonavides, ao receber a medalha Teixeira de Freitas, no Instituto dos Advogados Brasileiros, em 1998. Vide: Medalha Teixeira de Freitas: homenagem a Paulo Bonavides. Editora Destaque, 1999. Disponível em http://www.iabnacional.org.br/. Acesso em 18/12/2015.

${ }^{27}$ Esse perfil constitucional de transformação social é inclusive expressamente previsto no texto da Constituição da República de 1988, desde o seu preâmbulo.
} 


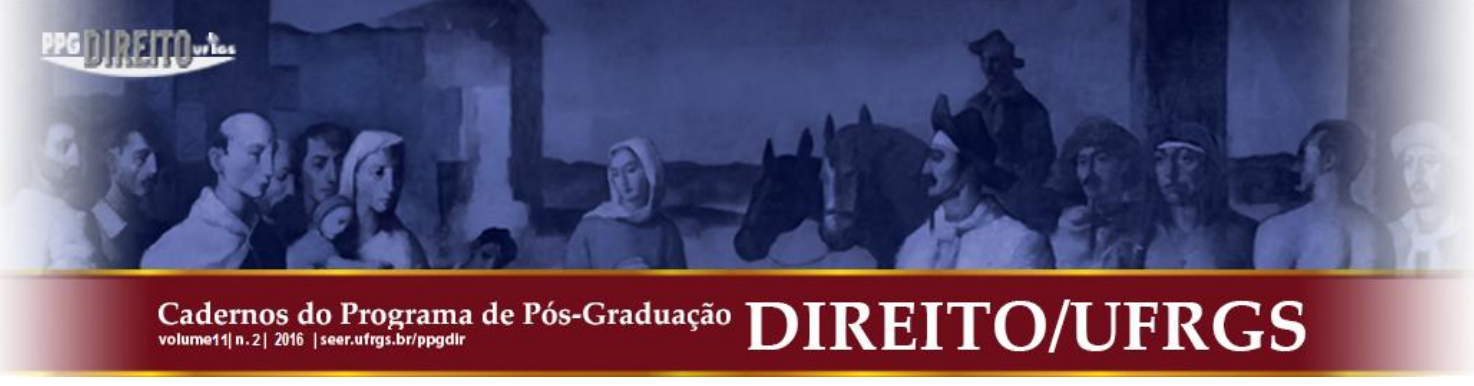

tradição, mais democrática, o constitucionalismo herdou o projeto de uma Constituição com eficácia normativa transformadora da realidade social. ${ }^{28}$

Para unir essas duas tradições, portanto, o constitucionalismo moderno idealizou um modelo de Constituição com força normativa que, além de regular a organização do poder e as fontes de Direito, prescreve diretamente direitos e deveres de eficácia imediata. Com precioso detalhamento, elenca Sanchís as principais características que o novo constitucionalismo assume nessa tarefa:

\begin{abstract}
Em suma, os elementos caracterizadores desse neoconstitucionalismo como Estado de Direito são: primeiro, o caráter normativo ou força vinculante. A Constituição não é um catecismo político ou uma guia moral dirigida ao legislador virtuoso, mas uma norma como qualquer outra que incorpora a pretensão de que a realidade se ajuste ao que se prescreve. Segundo, supremacia ou superioridade hierárquica no sistema de fontes (...). Terceiro, eficácia e aplicação direta (...), pois se a Constituição é uma verdadeira norma suprema se supõe que ela não requer a interposição de nenhum outro ato jurídico para despertar sua força vinculante. Quarto, garantia judicial. Como sabemos neste ponto as possibilidades são muito amplas: controle concreto e abstrato, a priori e a posteriori, aplicado a Cortes especiais (controle concentrado) ou a juízos ordinários (controle difuso), etc. (...) Quinto, presença de um denso conteúdo normativo que tem como destinatários os cidadãos em suas relações com poder e também com suas relações sociais horizontais de direito privado, conteúdo normativo este formado por princípios, direitos e diretrizes (...) chamados à aplicação em casos concretos. Em sexto e em último lugar a rigidez constitucional. Não há duvida de que o constitucionalismo resulta tanto mais forte quanto mais rígida for a alteração do texto, quanto mais inacessível se mostra frente a maioria legislativa (Tradução livre. Grifos nosso). ${ }^{29}$
\end{abstract}

Tem-se, então, a partir da perspectiva pós-positivista, a consolidação da noção de "Constituição embebedora",30 , irradiadora, capaz de condicionar a legislação, a jurisprudência, a doutrina, a ação dos agentes públicos e, ainda, influenciar diretamente a dinâmica das relações sociais. O teor constitucional passa a irradiar diretrizes sobre qualquer ato de criação, interpretação ou aplicação do Direito.

As Constituições assumem caráter dirigente, compromissório, de modo a conferir eficácia a seus valores e ideais, deixando para trás sua antiquada concepção meramente programática. A compreensão desse constitucionalismo como aspecto do Estado Democrático de Direito é relevante porque, por meio dele, as normas constitucionais vinculam a

\footnotetext{
${ }^{28}$ SANCHÍS, Luis Prieto. Sobre el neoconstitucionalismo y sus implicaciones. In: Justicia Constitucional y Derechos Fundamentales. Madrid: Trotta, 2003. p. 110.

${ }^{29}$ Idem. Ibidem. p. 117.

${ }^{30}$ STRECK, Lenio Luiz. A hermenêutica e as possibilidades de superação do positivismo pelo (neo)constitucionalismo. In: ROCHA, Leonel Severo; STRECK, Lenio Luiz (Org.). Constituição, sistemas sociais e hermenêutica. Porto Alegre: Livraria do Advogado, 2005. p. 161
} 


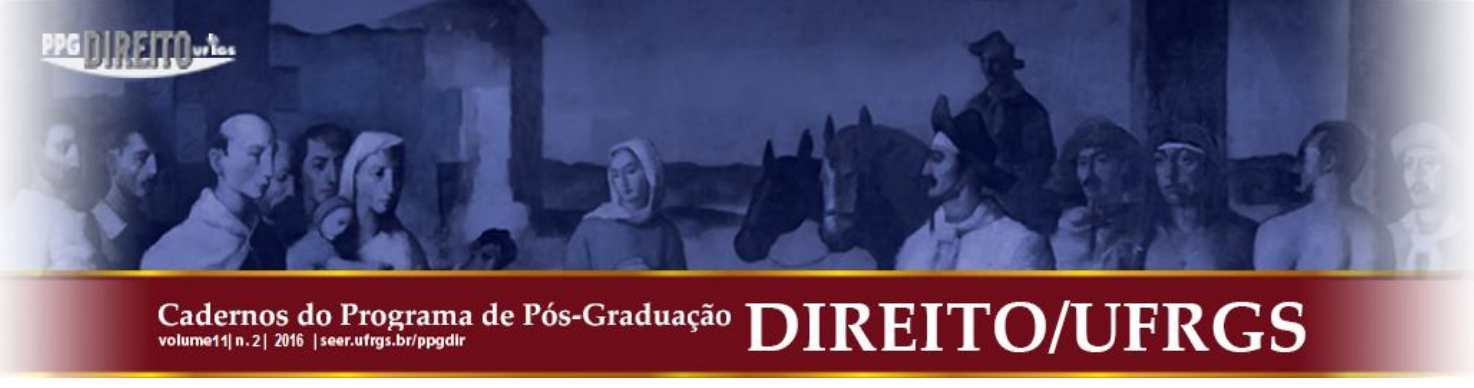

formulação, implementação, execução, controle e avaliação das políticas públicas engendradas com vista à promoção do máximo existencial.

No constitucionalismo, portanto, a Constituição passa a ser compreendida não como mero documento que estabelece direitos, mas sim como algo que efetivamente constitui ${ }^{31}$, e que, consequentemente, reconstitui a sociedade que dela se vale.

No caso brasileiro, associado em grande parte à desilusão com a política, bem como com a crise de representatividade do parlamento, o constitucionalismo afirma-se crescentemente como elemento basilar do Estado Democrático de Direito.

\subsection{Direitos Fundamentais Centrados na Dignidade da Pessoa Humana}

Referidos como núcleo da proteção da dignidade da pessoa humana ${ }^{32}$, os direitos fundamentais designam prerrogativas ostentadas pelo ordenamento jurídico com a finalidade de garantir uma convivência digna, livre e igual de todas as pessoas. Segundo José Afonso da Silva, "No qualificativo fundamentais acha-se a indicação de que se trata de situações jurídicas sem as quais a pessoa humana não se realiza, não convive e, às vezes, nem mesmo sobrevive". 33

Importante destacar que os direitos fundamentais, ao passo que designam direitos subjetivos, constituem elementos basilares da ordem constitucional objetiva no paradigma pós-positivista. Conquanto a dimensão subjetiva dos direitos fundamentais seja a mais enfatizada nas discussões jurídicas, por criar direitos e consequentes deveres diretamente na esfera pessoal do cidadão diante das relações jurídicas, ela convive reciprocamente com a dimensão objetiva, a partir da qual os direitos fundamentais constituem princípios básicos da ordem constitucional.

\footnotetext{
${ }^{31}$ Nesse sentido é a breve, porém emblemática expressão de Lenio Streck, resumidora do constitucionalismo: “a constituição compreendida como algo que constitui". STRECK, Lenio Luiz. A hermenêutica e as possibilidades de superação do positivismo pelo (neo)constitucionalismo. In: ROCHA, Leonel Severo; STRECK, Lenio Luiz (Org.). Constituição, sistemas sociais e hermenêutica. Porto Alegre: Livraria do Advogado, 2005. p. 163-164.

${ }^{32}$ Importante destacar a ressalva de Canotilho em relação à indevida subjetividade provocada pela identificação da dignidade da pessoa humana como nota da fundamentalidade. Conforme aduz o constitucionalista português, não se deve perder de vista que paralelamente aos direitos de índole subjetiva, atrelados à vida humana, existem outros direitos igualmente fundamentais de cunho objetivo, como é o caso daqueles atinentes à pessoa coletiva, às pessoas jurídicas e ao interesse social, como, por exemplo, os incisos XXI, XXIII, XXVIII, XIX do artigo $5^{\circ}$ da Constituição da República de 1988. In: MENDES, Gilmar Ferreira; BRANCO, Paulo Gustavo Gonet. Curso de direito constitucional. $9^{a}$ ed. São Paulo: Saraiva. 2014. p. 140.

${ }^{33}$ SILVA, José Afonso da. Curso de Direito Constitucional positivo. São Paulo: Malheiros, 2002. p. 182. 


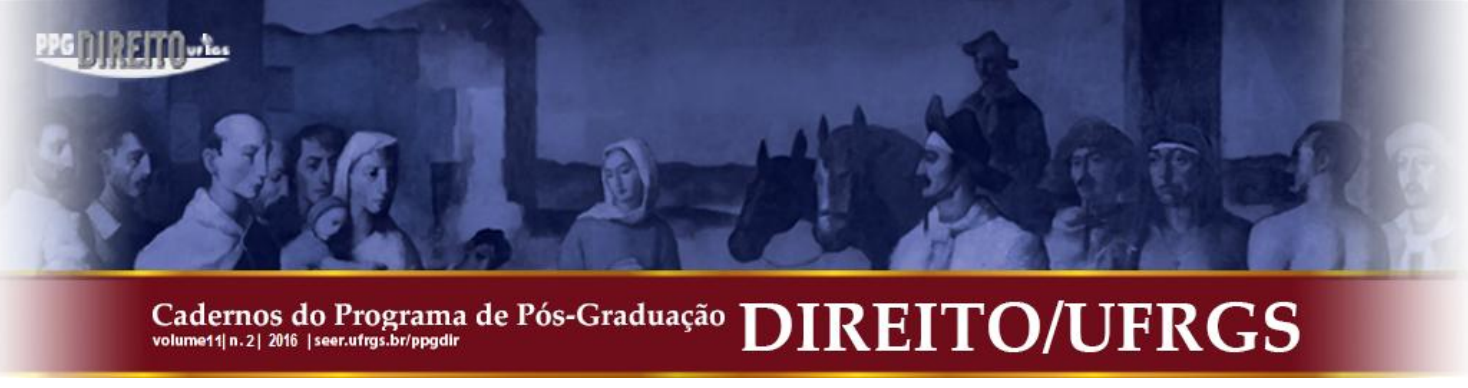

Nesse sentido objetivo, os direitos fundamentais transcendem a função de meros garantidores de posições individuais, passando a serem observados também como normas que representam os principais valores da sociedade, capazes inclusive de irradiar esses valores por todo o sistema jurídico, conformando a interpretação e a aplicação em todos os ramos do Direito. No contexto de constitucionalização de valores sociais e princípios empreitado pelo pós-positivismo, portanto, não se pode olvidar o enfoque nos direitos fundamentais como base do ordenamento jurídico no Estado Democrático de Direito. ${ }^{34}$

E, em razão dessa dimensão objetiva irradiante, o cenário axiológico criado pelos direitos fundamentais pode até mesmo legitimar interpretações restritivas a outros direitos individuais envolvidos. É o caso, por exemplo, das sucessivas decisões judiciais no sentido da abusividade de revistas íntimas praticadas no ambiente laboral. ${ }^{35}$ Nesses casos, entendem os Tribunais, com base na perspectiva objetiva dos direitos fundamentais, que o direito patronal à liberdade de gestão, à autonomia da vontade e à proteção da propriedade limita-se diante do necessário resguardo à dignidade do trabalhador.

Destaque-se como importante consequência da dimensão objetiva dos direitos fundamentais o dever de proteção imputado ao Estado, em que este, por meio dos seus três poderes, deve adotar medidas positivas de proteção efetiva dos direitos fundamentais. É dizer, sob esse enfoque objetivo os direitos fundamentais correspondem a um direito a prestação positiva, na medida em que cobram a adoção de providências materiais, políticas ou jurídicas, de resguardo dos bens tutelados pelos direitos fundamentais. ${ }^{36}$

São essas, portanto, as principais características dessa nova fase do pensamento jurídico, apelidada de pós-positivista, que muda a face do Direito para seguir as tendências e clamores por justiça social e valorização humana no novo século.

\footnotetext{
${ }^{34}$ MENDES, Gilmar Ferreira; BRANCO, Paulo Gustavo Gonet. Curso de direito constitucional. $9^{a}$ ed. São Paulo: Saraiva. 2014. p. 167.

${ }^{35}$ Rememore-se o paradigmático caso de um conferente que ajuizou reclamação trabalhista contra uma grande empresa de segurança e transporte de valores, em que o Tribunal Superior do Trabalho manteve a condenação por danos morais. Naquela ocorrência, o conferente de numerários era submetido a revistas íntimas diárias, nas quais era revistado de cueca ou nu em frente a colegas e ainda era obrigado a dar uma "voltinha" a pedido da chefia. No caso, assentou o relator que mesmo sendo a revista uma prerrogativa inserida no âmbito do poder fiscalizatório do empregador, como desdobramento do poder diretivo, encontra rígidos limites no princípio maior da dignidade da pessoa humana, consubstanciado na hipótese pelo direito à inviolabilidade da honra e da intimidade. BRASIL. Tribunal Superior do Trabalho. TST-AIRR -166100-56.2009.5.15.0043. Min. Rel. Maurício Godinho Delgado, julgado em 08/05/13, publicado DJe em 10/05/2013. Disponível em <http://www.tst.jus.br/noticias/-/asset_publisher/89Dk/content/materia-especial-abordou-a-revista-intima-noambiente-de-trabalho> Acesso em 18/11/2015.

${ }^{36}$ MENDES, Gilmar Ferreira; BRANCO, Paulo Gustavo Gonet. Curso de direito constitucional. $9^{\mathrm{a}}$ ed. São Paulo: Saraiva. 2014. p. 168.
} 


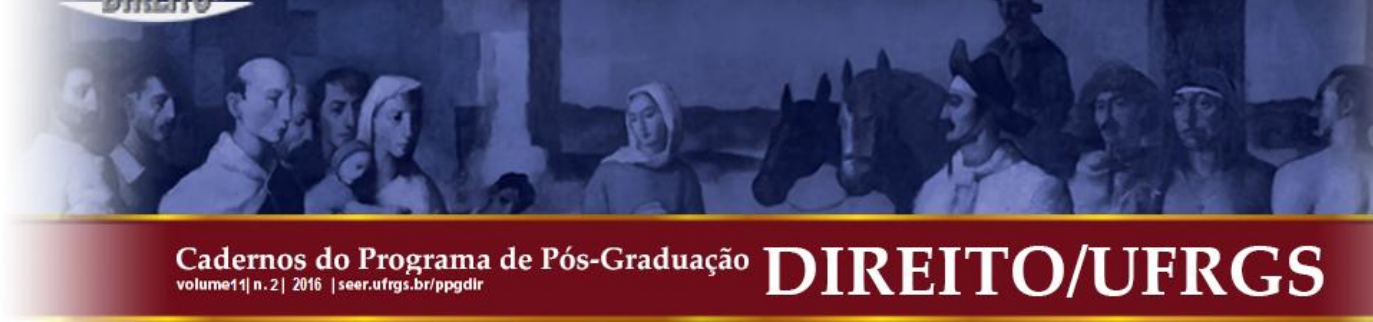

\section{O DIREITO DO TRABALHO PÓS-POSITIVISTA}

\subsection{O Movimento Pendular da História Constitucional do Direito do Trabalho em face das Transformações Socioeconômicas}

O Direito do Trabalho possui como elemento nuclear o trabalho livre dirigido ao processo produtivo. Posiciona-se, daí, diante de duas forças antagônicas, porém interdependentes: o trabalho humano e a produção econômica. Por esse motivo, sua evolução ao longo do tempo está intrinsecamente atrelada às transformações socioeconômicas e políticas havidas na história da humanidade.

Passemos, então, à análise dos fatores econômicos, sociais e políticos que envolveram o processo de formação e consolidação do Direito do Trabalho.

Durante o século XIX, reinava na sociedade ocidental a opção político-ideológica liberal $^{37}$, tipicamente individualista. A autonomia da vontade e a exaltação da propriedade privada figuravam como pilares do pensamento jurídico à época. Reinava a exploração descontrolada da força de trabalho pelo capitalismo, em um sistema econômico expansionista ancorado no pensamento civilista, com sua forte característica individualista e patrimonialista.

Destaque-se que essa fase liberal-individualista do Estado flertava com a teoria positivista do Direito, que emprestava àquele sua estrutura lógico-formal acrítica, neutra, alheia a valores morais, viabilizando, pois, o ideário de preeminência do capital sobre o trabalho humano.

De acordo com a análise de Mauricio Godinho Delgado, esse contexto remonta à primeira fase histórica do Direito do Trabalho, de manifestações incipientes e esparsas, caracterizada pela quase desregulamentação trabalhista, à exceção de pontuais leis dirigidas tão-somente a reduzir a violência brutal da exploração sobre o trabalho de mulheres e

\footnotetext{
${ }^{37}$ O regime político-jurídico do Estado Liberal consolidou-se a partir das Revoluções Burguesas no final do século XVIII, em que a classe burguesa emergente detinha o poder econômico, enquanto o poder político estava sob o domínio da nobreza. O princípio da não intervenção do Estado na economia defendido pelo Estado Liberal foi, portanto, uma estratégia burguesa para evitar a ingerência dos antigos senhores feudais e monarcas na economia da época, garantindo a liberdade individual para a expansão dos seus negócios e consequente maximização do lucro. In: STRECK, Lenio Luiz; MORAIS, José Luis Bolzan de. Ciência política e teoria geral do estado. $3^{\mathrm{a}}$ ed. Porto Alegre: Livraria do Advogado, 2003. p. 49-52.
} 


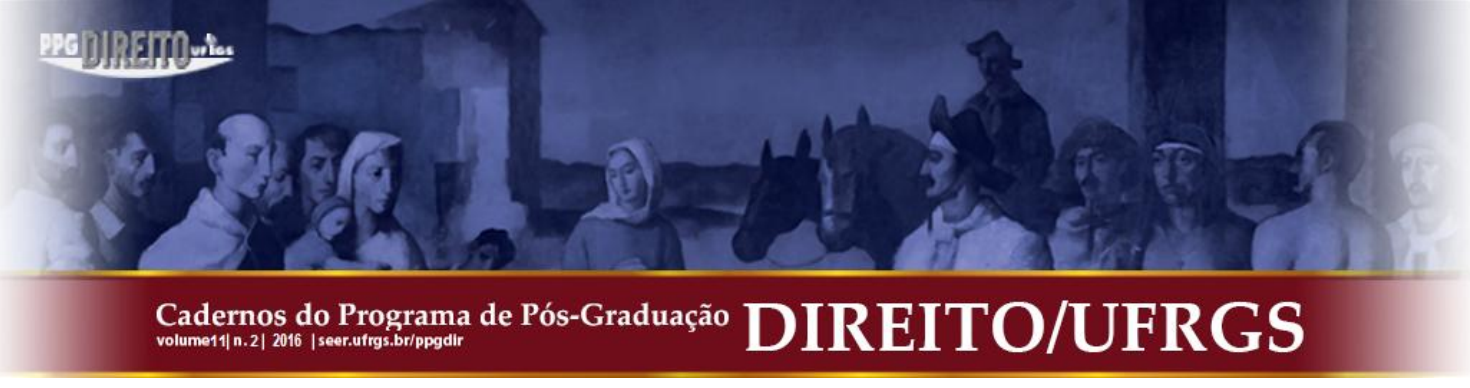

menores. O espetro normativo trabalhista, portanto, ainda era disperso, mostrando-se incapaz de constituir um ramo jurídico próprio e autônomo. ${ }^{38}$

Os efeitos dessa quase desregulamentação trabalhista não demoraram a surgir. A exploração desmedida do trabalho humano no período pós-Revolução Industrial fez eclodir ações coletivas sistemáticas ${ }^{39}$ dos segmentos sociais dominados pela estrutura socioeconômica da época industrial, com um conjunto de reivindicações tendentes à melhoria das condições do ambiente de trabalho. Remontam a essa época, por exemplo, a conquista da jornada limitada a 10 (dez) horas diárias na França e Inglaterra, bem como o direito de associação e greve. ${ }^{40}$

Em razão das conquistas alcançadas pelo movimento operário nesse período histórico da década de 40 do século XIX até a Primeira Guerra Mundial, a fase é denominada de sistematização e consolidação do Direito do Trabalho, seguida da fase de institucionalização. Nesta, marcada pela criação da Organização Internacional do Trabalho - OIT (1919) e pela Constituição de Weimar ${ }^{41}$, o Direito do Trabalho se constitucionaliza e se incorpora às ordens jurídicas dos países democráticos.

No caso do Brasil, observou-se um atraso na fase de institucionalização. Em meio a um período político centralizador e autoritário getulista (1930 a 1945), era idealizada a Consolidação das Leis do Trabalho - CLT (Decreto-Lei n. ${ }^{0}$ 5.452/1943), que consolidou diversas leis trabalhistas esparsas anteriores, como a fixação da jornada de oito horas diárias para comerciários e industriários (Decreto n. 21.186 e 21.364/1932), a criação da Carteira de Trabalho e Previdência Social - CTPS (Decreto n. ${ }^{\circ}$ 21.175/1932) e férias (Decreto n. ${ }^{\circ}$ $23.103 / 1933){ }^{42}$

\footnotetext{
${ }^{38}$ DELGADO, Maurício Godinho. Curso de Direito do Trabalho. $14^{a}$ Ed. São Paulo: LTr, 2015. p. 97-100.

${ }^{39}$ São exemplos de manifestações coletivas desse período doutrinas socialistas como o Manifesto Comunista de Karl Marx e Friedrich Engels (1848), ilustrado pela sua célebre frase: "proletários de todos os países, uni-vos!", bem como os movimentos cartistas na Inglaterra e na França, ocorridos mesma década do século XIX, que apesar da inicial resistência do governo aos reclamos sociais (redigidos em documento intitulado Carta do Povo - daí a denominação do movimento), provocou mudanças efetivas, como a regulamentação do trabalho feminino e infantil, a permissão de associações políticas e a limitação da jornada de trabalho diária a 10 horas.

${ }^{40}$ DELGADO, Maurício Godinho. Curso de Direito do Trabalho. 14 ${ }^{\mathrm{a}}$ Ed. São Paulo: LTr, 2015. p. 100-101.

${ }^{41}$ A Constituição de Weimar, oficialmente Constituição do Império Alemão, vigente na República de Weimar (1919-1933), representa o auge da crise do Estado Liberal do século XVIII e a ascensão do Estado Social do século XX, uma vez que consagrou direitos sociais superando a organização do Estado em função do indivíduo. In: STRECK, Lenio Luiz; MORAIS, José Luis Bolzan de. Ciência política e teoria geral do estado. $3^{\text {a }}$ ed. Porto Alegre: Livraria do Advogado, 2003. p. 70-71.

${ }^{42}$ DELGADO, Maurício Godinho. Curso de Direito do Trabalho. 14ª Ed. São Paulo: LTr, 2015. p. 101-102 e 114-118.
}

Cadernos do Programa de Pós-Graduação em Direito PPGDir./UFRGS | Edição Digital | Porto Alegre | Volume XI | Número 2 | 2016 | P. 314 - 342 


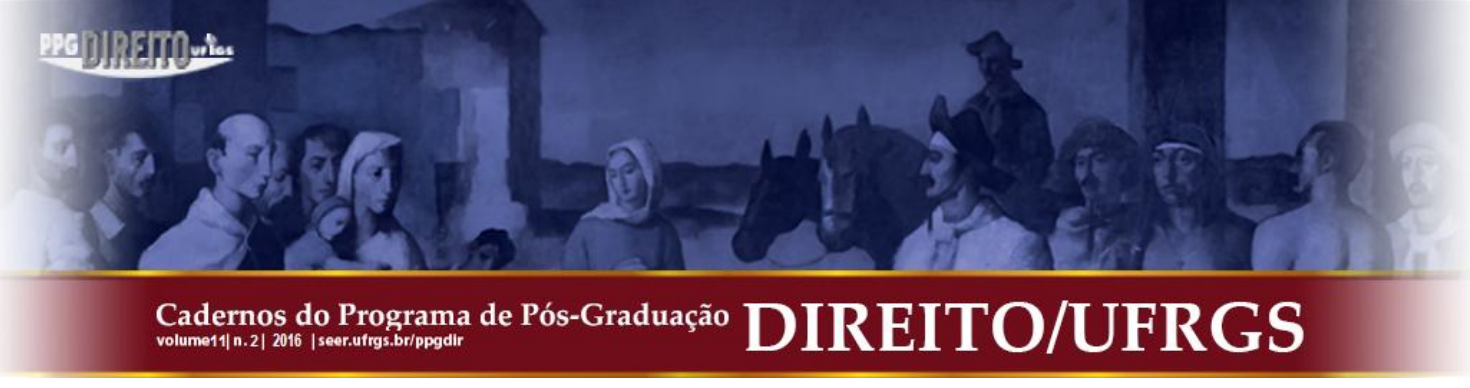

A essa época de institucionalização mundial do Direito do Trabalho (1919) até então imperava o viés político liberal clássico do Estado, referido acima, que sofreu seu primeiro abalo com a crise da Bolsa de Nova Iorque em 1929. A grande depressão econômica trouxe como consequência pobreza e desemprego por todo o mundo. A partir da crise, as pressões sociais para solução do caos socioeconômico inauguraram uma nova fase política, denominado Estado de Bem-Estar Social (Welfare State), notabilizado na busca da justiça social por meio de atuação proativa do Estado destinada à concretização dos interesses da coletividade, mediante direitos sociais. Iniciado com o programa New Deal norte-americano, o Estado de Bem-Estar Social se espalhara para o mundo ao fim da devastadora Segunda Guerra Mundial.

A hegemonia do Estado de Bem-Estar Social intensificou o fenômeno de constitucionalização do Direito do Trabalho. Os direitos sociais - inclusive os trabalhistas passaram a ser incorporados às Constituições das principais potências econômicas na qualidade também de direitos fundamentais, tal como ocorrido com as Constituições Democráticas pós-1945 da França (1946), da Itália (1947) e da Alemanha (1949) e pós-1970 de Portugal (1976) e da Espanha (1978). Marcada por reivindicações igualitárias, a ideologia política do Estado Social fez alçar a patamar constitucional novos valores sociais e princípios que enalteciam o trabalho humano, como dignidade da pessoa humana, justiça social e valorização do trabalho humano. ${ }^{43}$

Contudo, a partir da crise do petróleo, iniciada em 1973, ocorre nova reviravolta política, econômica e social. A crise abalou novamente a economia mundial, inclusive com uma alta inflacionária nunca antes vista, acirrando os cortes orçamentários públicos e privados, além de elevar novamente as taxas de desemprego. Com o déficit fiscal do Estado, os gastos com políticas sociais foram prejudicados. Em um cenário de escassos recursos, as empresas aumentavam a busca por tecnologia para substituição da mão de obra humana, além de criarem novas formas de organização empresarial para redução de custos, como a terceirização de serviços e a exploração de cooperativas de serviços. ${ }^{44}$ Diante da crise, os postos de trabalho que ainda restavam eram explorados ao máximo, agravado pela intensa oferta de mão de obra desempregada.

\footnotetext{
${ }^{43}$ DELGADO, Maurício Godinho. Curso de Direito do Trabalho. 14a Ed. São Paulo: LTr, 2015. p. 102.
}

${ }^{44}$ Idem. Ibidem. p. 103. 


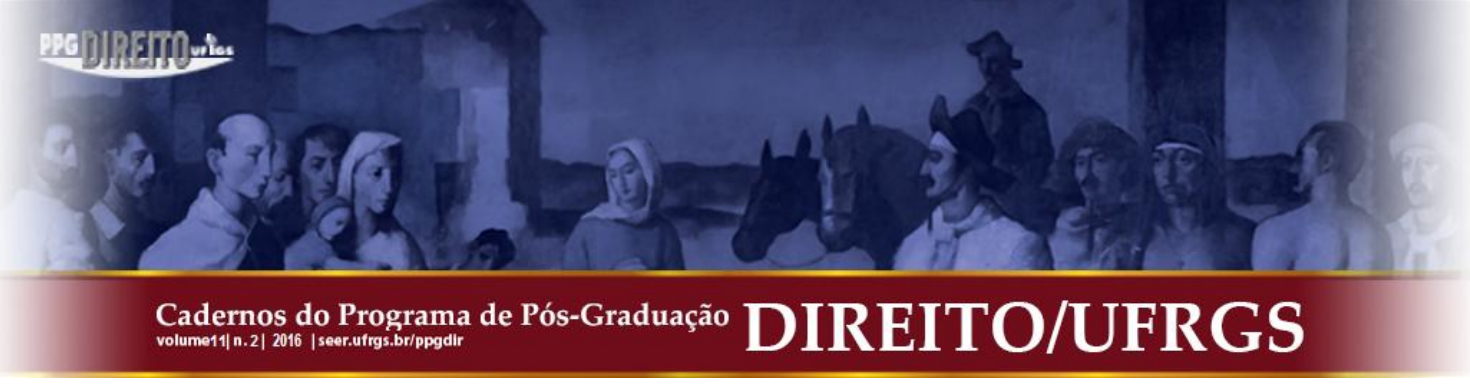

Em respostas ao grave quadro socioeconômico, desponta uma nova ideologia política denominada Neoliberal, afirmando um pensamento desregulatório do Estado de Bem-Estar Social. Segundo o historiador Perry Anderson, os neoliberais enxergavam as origens da crise localizadas no "poder excessivo (...) do movimento operário, que havia corroído as bases de acumulação capitalista com suas pressões reivindicativas sobre os salários e com sua pressão parasitária para que o Estado aumentasse cada vez mais os gastos sociais" ${ }^{\text {"45 }}$. Representantes das maiores economias do mundo ${ }^{46}$ pregavam incessantemente diretrizes em favor do Estado Mínimo para a recuperação econômica, fato que atingia as políticas sociais, dentre elas o Direito do Trabalho.

Eis a fase de crise do Direito do Trabalho ${ }^{47}$, em que o labor humano era enxergado como valor estritamente utilitário. Nessa linha materialista, o trabalhador era tido como uma simples peça de um maquinário voltado cegamente para o lucro. A condição humana estava desprestigiada no ambiente laboral. Junto ao desprestígio individual caminhava também a involução da identidade social e coletiva dos trabalhadores. Enfim, o neoliberalismo furtavase em enxergar o direito ao trabalho digno. ${ }^{48}$

Foi nessa fase neoliberal generalizada no mundo ocidental do fim do século XX que ganharam corpo inclusive as teorias flexibilizantes do Direito do Trabalho, ou, em uma proposta mais radical, a proposta de desregulamentação das normas protecionistas trabalhistas. Sob o argumento da necessidade da recuperação econômica, referidas propostas buscavam novos modelos de gestão trabalhista, calcados na exploração livre ou subregulamentada do trabalho, sob a míope concepção de que a crise socioeconômica do período se devia à dita excessiva proteção do trabalho humano.

Diante do exposto, nota-se que as fases trabalhistas estiveram entranhadas à dinâmica do cenário econômico, social e político, influenciando e sendo influenciadas em um movimento cíclico ao longo da história. Quando vigente o Estado Liberal, o Direito do

\footnotetext{
${ }^{45}$ ANDERSON, Perry. Balanço do neoliberalismo. In: SADER, Emir (org). Pós-neoliberalismo: as políticas sociais e o Estado democrático. São Paulo: Paz e Terra, 1996. p. 10.

${ }^{46}$ A ideologia política neoliberal desenvolve-se a partir do governo de Margaret Thatcher na Inglaterra de 1979, de Ronald Reagan nos EUA de 1980, bem como de Helmut Kohl na Alemanha de 1982. No Brasil, a ideologia neoliberal influenciou principalmente os governos de Sarney (1985), Fernando Collor de Mello (1990), Itamar Franco (1992) e os dois mandatos de Fernando Henrique Cardoso (1995).

${ }^{47}$ DELGADO, Maurício Godinho. Curso de Direito do Trabalho. 14 ${ }^{\mathrm{a}}$ Ed. São Paulo: LTr, 2015. p. 103-104.

${ }^{48}$ DELGADO, Gabriela Neves. Estado Democrático de Direito e Direito Fundamental ao Trabalho Digno. In: ; DELGADO, Maurício Godinho. Constituição da República e Direitos Fundamentais: dignidade da pessoa humana, justiça social e direito do trabalho. São Paulo: LTR, 2015. p. 57.
} 


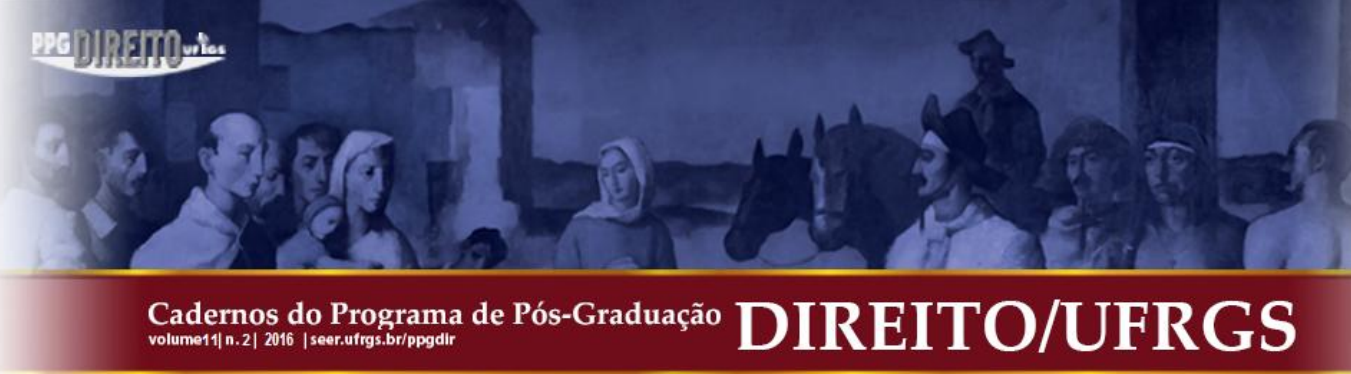

Trabalho via-se oprimido diante do ideal individual-patrimonialista e da perspectiva juspositivista; quando passado ao Estado de Bem-Estar Social, o Direito do Trabalho agigantava-se a ponto de se constitucionalizar mundo afora. E agora, diante desse movimento pendular observado na história trabalhista, o advento do ideal neoliberalista faria o Direito do Trabalho retornar à fase de letargia ${ }^{49}$ antes vista no liberalismo clássico? Dito de forma mais pragmática e dramática, vingaria a catastrófica previsão neoliberal de uma sociedade com trabalho desregulamentado?

\subsection{A Renovação Juslaboral: o Direito do Trabalho no Constitucionalismo Democrático Brasileiro}

A evolução social após os traumas de regimes totalitários e das grandes guerras mundiais levou à concepção não apenas do Estado Social de Direito, mas à sua evolução: O Estado Democrático de Direito.

O Estado Democrático é caracterizado pela convivência social livre, justa e solidária, em que o poder emana do povo - o povo soberano exercendo-o diretamente ou por meio de representantes eleitos -, pelo povo - mediante democracia participativa no processo decisório livre - e para (todo) o povo, cumprindo a finalidade ética do poder e respeitando a pluralidade de ideias e culturas da sociedade. ${ }^{50}$

A democracia na história humana distinguiu-se e destacou-se por combinar princípios de liberdade, igualdade e fraternidade na convivência social, de modo a lançar luz e dar voz a indivíduos e grupos sociais antes marginalizados, destituídos de poder e riqueza. ${ }^{51}$ É nesse novo paradigma que se intenta realizar o princípio democrático por meio da efetividade dos direitos fundamentais da pessoa humana.

Para se alcançar essa pretensiosa qualidade democrática, essencial que o Estado não apenas reconheça no plano formal os direitos fundamentais individuais, políticos e sociais tal como observado nas fases Liberal e Social anteriores. Mais que isso, essencial que se

\footnotetext{
${ }^{49}$ O sentido figurado da palavra "letargia", emprestada da neurociência, foi utilizada como sono profundo, apatia, estado de abatimento e depressão, inércia. In: FERREIRA, Aurélio Buarque de Holanda. Novo Dicionário Eletrônico Aurélio. Edição eletrônica. Versão 5.0. Rio de Janeiro: Editora Positivo, 2004.

${ }^{50}$ SILVA, José Afonso da. Curso de Direito Constitucional positivo. São Paulo: Malheiros, 2002. p. 122.

${ }^{51}$ DELGADO, Maurício Godinho. Direitos fundamentais na relação de trabalho. Revista de direitos e garantias fundamentais, $\mathrm{n}^{\mathbf{0}}$ 2, 2007. p. 13.
} 


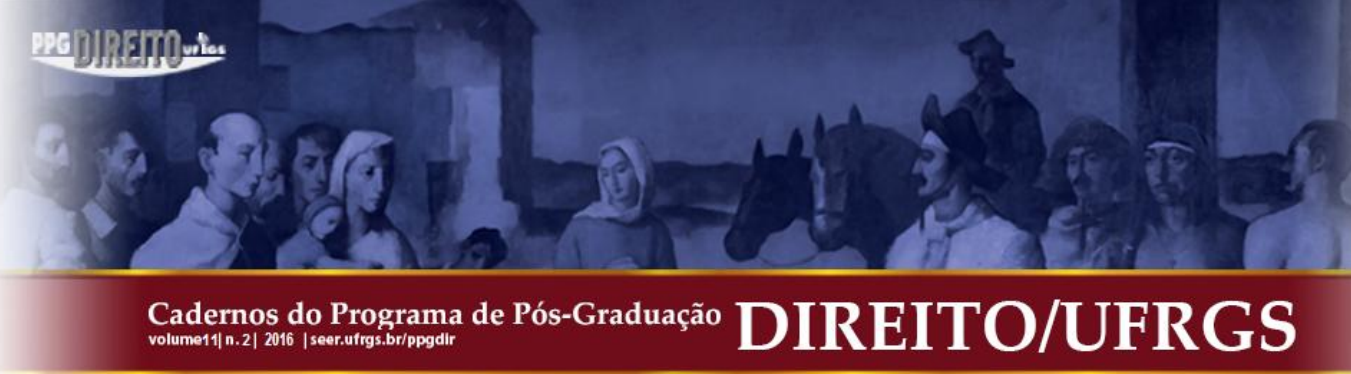

garantam a todos os indivíduos condições suscetíveis de se alcançar efetivamente e concretamente o pleno exercício desses direitos fundamentais.

Nesse contexto foi conformada a ordem constitucional nacional vigente, resultado de um amplo processo de discussão oportunizado com a redemocratização do país após mais de duas décadas de ditadura militar. Caracterizada por uma evidente exaltação dos direitos fundamentais em reação ao regime restritivo, a Constituição Cidadã não economizou esforços em municiar a nação com um inovador catálogo amplo de direitos fundamentais sociais positivados no texto constitucional ou mesmo não expressos mas com ele consonante (CF, art. $\left.5^{\circ}, \S 2^{\circ}\right)$. Inovação ainda maior certamente advém do seu artigo $5^{\circ}, \S 1^{\circ}$, que concede aplicabilidade imediata a esses direitos sociais, avançando ao mero conteúdo dirigente. ${ }^{52}$

O tom democrático da Constituição de 1988, então, demanda uma superação da visão dos direitos sociais - inclusive os trabalhistas - como meras normas programáticas. Seu papel abrange o comprometimento com a adoção de medidas de efetivação dos direitos fundamentais voltadas ao reconhecimento universal de direitos e consequente alcance da justiça social. A simples previsão de tutela social em diplomas legais, se tida como simplória carta de intenções, não atenderia ao pressuposto democrático de efetivação dos valores da soberania popular, liberdade e igualdade inclusiva. ${ }^{53}$

Destaca-se, daí, o clamor por uma reanálise - agora pós-positivista - do Direito do Trabalho. O valor trabalho ocupa posição central na ordem constitucional, em suas facetas econômica e social, apresentando-se como eficiente mecanismo de distribuição de renda e de atenção social no âmbito do capitalismo. Associa-se aos propósitos da afirmação da dignidade da pessoa humana e da materialização da justiça social. A reflexão sobre a efetividade dos direitos fundamentais trabalhistas, portanto, posiciona-se nitidamente no centro de convergência entre o Estado Democrático de Direito, os direitos fundamentais dele decorrentes e as condições materiais para o gozo efetivo desses direitos.

\footnotetext{
52 SARLET, Ingo Wolfgang. A eficácia dos direitos fundamentais. $11^{\text {a }}$ edição. Porto Alegre: Livraria do advogado, 2012. E-book. ISBN 978-85-7348-789-3. p. 53.

${ }^{53}$ SILVA, José Afonso da. Curso de Direito Constitucional positivo. São Paulo: Malheiros, 2002. p. 126. 


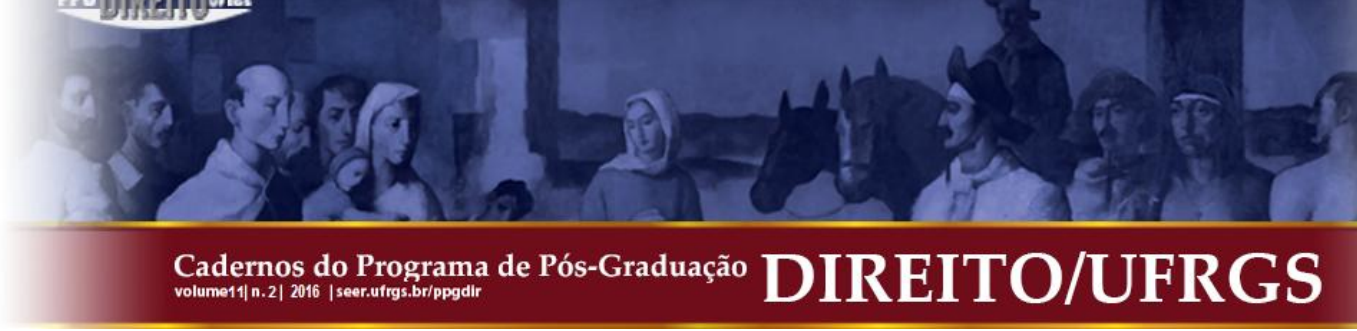

\subsection{O Direito do Trabalho no Contexto Pós-positivista}

Para que o Direito do Trabalho voltasse ao protagonismo como garantidor da justiça social, da igualdade, da valorização do trabalho humano e da função social da propriedade, com evidenciação do seu principal intuito concretizador dos direitos humanos fundamentais, mostrava-se essencial uma nova maneira de pensá-lo.

Necessário se mostrava uma base teórico-filosófica para fundamentar o enaltecimento do trabalho enquanto suporte de valor da dignidade do ser humano. As indagações filosóficas acerca do trabalho demandavam uma nova ferramenta para compreensão do verdadeiro sentido do direito fundamental ao trabalho digno.

A tendência jusfilosófica pós-positivista, embasada na abertura axiológica do sistema jurídico, na normatividade dos princípios jurídicos, na exaltação da Constituição como fonte de irradiação normativa e na efetividade dos direitos fundamentais apresenta-se, então, como uma tábua de salvação para a fase crítica do direito trabalhista brasileiro vivenciado nas últimas décadas no contexto neoliberal.

O Direito do Trabalho pós-positivista se destaca principalmente a partir da reflexão da importância do trabalho prestado em condições dignas, e, mais que isso, pela necessidade democrática de se concretizar esse resguardo da dignidade na prática das relações trabalhistas. Por meio de uma reanálise pós-positivista, o Direito do Trabalho se mostra capaz de resgatar os fundamentos constitucionais que enaltecem o trabalho como locus da dignidade do ser humano.

Para tanto, o Direito do Trabalho, na perspectiva pós-positivista, exige do intérprete uma nova consciência, provocadora da noção de que estar protegido pelo trabalho significa não necessariamente mero fomento à criação de postos de trabalho, mas também - e principalmente - a concretização, no plano constitucional, dos direitos fundamentais que asseguram uma vida minimamente digna ao trabalhador. Nesse sentido é a oportuna abordagem da professora Gabriela Neves Delgado, que, ao tratar do direito fundamental ao trabalho digno, destaca o cuidado com o sentido da expressão "direito ao trabalho". Segundo a autora, caso tomada literalmente, a expressão poderia conduzir à interpretação fria e avalorativa de que referido direito se trata de mera criação numérica de postos de trabalho, ainda que precários. Porém, na atual ordem constitucional “do Estado Democrático de Direito 


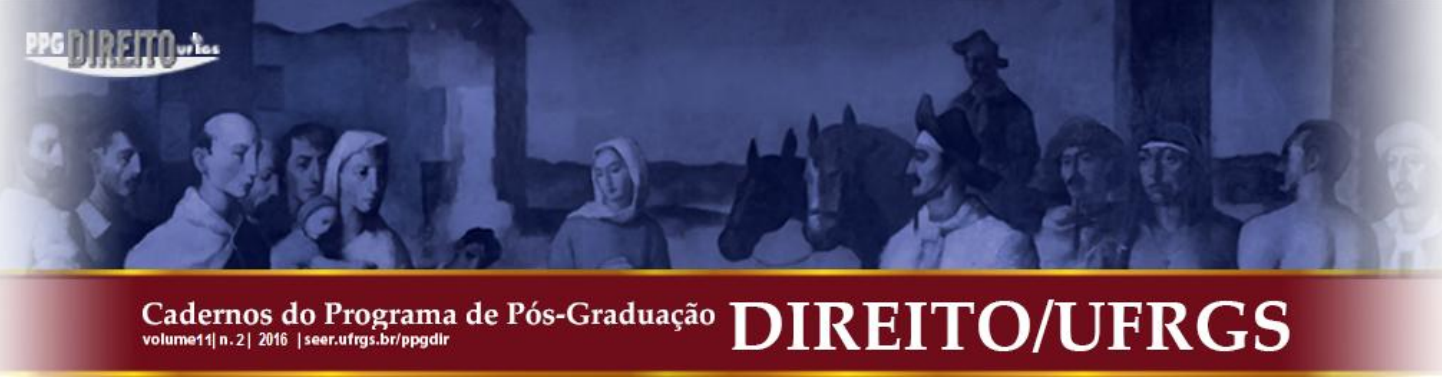

não se concebe o trabalho como simples sujeição, mas sim como direito, isto é, como vantagem protegida juridicamente". ${ }^{54}$

Dito de modo mais concreto, observado o plano normativo constitucional, a visão póspositivista provoca o direcionamento do intérprete à noção de que as relações trabalhistas se inserem no contexto de centralidade da Lei Maior, carreadoras de valores e princípios enaltecedores da justiça social (art. 170, caput, da CF), da valorização do trabalho humano digno (art. $1^{\circ}$, III e IV, da CF), da vedação ao retrocesso social (art. $7^{\circ}$, caput, da CF) ou, mais que isso, do contínuo progresso social ao longo do tempo. A propósito, essa notável compreensão constitucional do Direito do Trabalho levou o constituinte à inserção das normas trabalhistas nos dois primeiros Títulos da Constituição da República de 1988 (Dos Princípios Fundamentais e Dos Direitos e Garantias Fundamentais), além de fazer o valor social do trabalho abrir os Títulos VII (Da Ordem Econômica e Financeira) e VIII (Da Ordem Social).

No contexto do Estado Democrático de Direito, a visão pós-positivista do Direito do Trabalho provoca, outrossim, a preocupação com a efetividade dos direitos fundamentais, de modo a alçar ao ápice do sistema jurídico a pessoa humana e sua respectiva dignidade. ${ }^{55}$ Diante da notável tendência de decréscimo da tutela protetiva ${ }^{56}$ via propostas legislativas de flexibilização e até mesmo de desregulamentação das normas laborais ${ }^{57}$, fomentada pelo atual contexto de adversidade econômica patronal, sobressai-se a importância da vigilância de concretização dos direitos fundamentais trabalhistas, de modo a se trazer ao sistema jurídico e

\footnotetext{
${ }^{54}$ DELGADO, Gabriela Neves. Estado Democrático de Direito e Direito Fundamental ao Trabalho Digno. In: ; DELGADO, Maurício Godinho. Constituição da República e Direitos Fundamentais: dignidade da pessoa humana, justiça social e direito do trabalho. São Paulo: LTR, 2015. p. 64-65.

55 DELGADO, Maurício Godinho. Constituição da República, Estado Democrático de Direito e Direito do Trabalho Digno. In: ; DELGADO, Gabriela Neves. Constituição da República e Direitos Fundamentais: dignidade da pessoa humana, justiça social e direito do trabalho. São Paulo: LTR, 2015. p. 48.

$56 \mathrm{O}$ atual decréscimo de tutela social trabalhista promovido pelas flexibilizações das regras laborais tem como exemplo as discussões parlamentares acerca da ampliação da terceirização dos serviços (Projeto de Lei n. ${ }^{\circ}$ 4330/2004), o relaxamento da proteção trabalhista em favor da concretização do mandamento constitucional de tratamento favorecido às pequenas empresas, promovido principalmente no âmbito da Lei Complementar n. ${ }^{\circ}$ 123/2006 (vide, exemplificativamente, os artigos 51, 55 e 58 da Lei Complementar n. ${ }^{\circ}$ 123/2006, alterada pela recente Lei Complementar . $^{\circ}$ 147/2014), bem como, ainda, a recente discussão legislativa havida no âmbito da Medida Provisória n. ${ }^{\circ}$ 680/2015, acerca da prevalência da negociação coletiva sobre as disposições legais em matéria trabalhista - proposta esta conhecida como "prevalência do negociado sobre o legislado".

${ }^{57}$ Oportuno relembrar que a construção do Direito do Trabalho, como regulamentação positiva das relações de produção no modelo capitalista, representou relevantes conquistas do trabalhador frente ao poderio econômico do empregador, ante a debilidade da autonomia negocial entre partes com poderes assimétricos. Permitir que as proteções legais, representativas de um mínimo limite à imposição da força do empregador sobre o trabalhador, sejam reduzidas sob o pretexto de uma maior negociação adaptativa entre as partes, representa verdadeira alienação do progresso social e da valorização do trabalho humano. COUTINHO, Aldacy Rachid. O princípio da proteção revisitado. In: Revista Bonijuris, Curitiba, vol. 13, nº 452, jul. 2001. p. 5 e ss.
} 


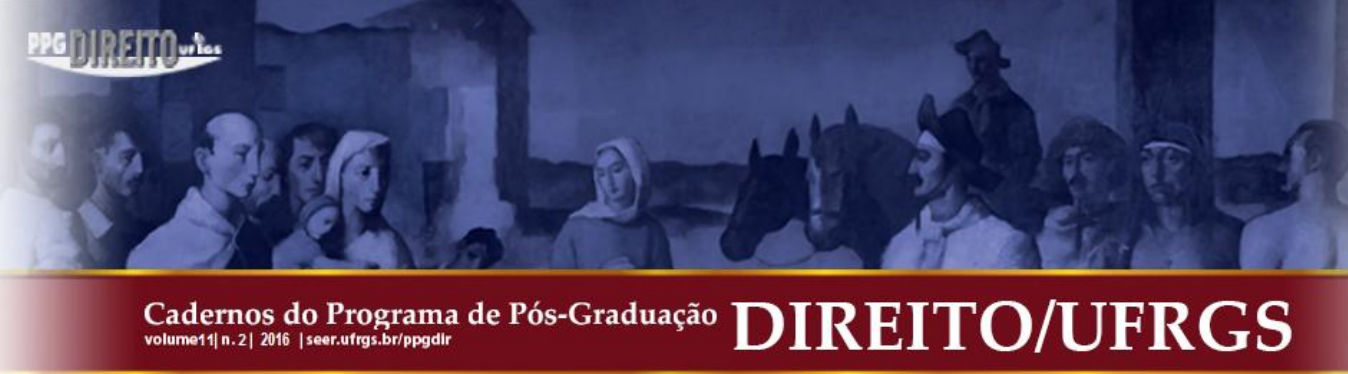

às relações sociais a clarividente predileção constitucional de tutela do trabalho humano digno.

A partir de um contexto pós-positivista do Direito do Trabalho e tendo em vista a rica atenção dada pela quase trintenária Carta Cidadã de 1988 às normas trabalhistas, podemos então nos assegurar da existência de uma maturidade de organização política e jusfilosófica capaz de proteger o Direito do Trabalho contra qualquer nova investida do poder econômico. Que assim se faça pelo intérprete do Direito laboral.

\section{CONSIDERAÇÕES FINAIS}

A tradicional concepção positivista do Direito, indiferente à interação entre o direito e o meio a que ele se aplica, mostrou-se insuficiente ao longo do tempo para sua pretensiosa ambição da pacificação social. Diante da crescente complexidade da sociedade moderna, as regras jurídicas e a atividade interventiva do Estado se multiplicavam, passando a gerar decisões circunstanciais e imprevisíveis, fazendo cair por terra o grande pilar do positivismo. A certeza das leis se esvaía em paulatina insegurança.

A nova fase da humanidade, repleta de clamores e incertezas, marcada por profundos traumas históricos decorrentes de regimes totalitários e de duas guerras mundiais, pugnava pela busca de um Direito efetivo. O Direito não mais poderia se mostrar alheio às questões morais e à realidade social, política e econômica vivenciadas intensamente no presente mundo.

As relações sociais multifacetadas, inclusive no âmbito trabalhista, exigiam um novo viés jusfilosófico, capaz de superar as limitações positivistas - notadamente a impraticável pretensão de submissão exata do fato à lei como se esta fosse capaz de contemplar universalmente todas as hipóteses de conflitos -, mas sem que se perdesse o legado positivista atinente à segurança e objetividade jurídica.

Por meio da exaltação dos valores pulsantes na sociedade, do reconhecimento de normatividade nos princípios, da compreensão da Constituição como norma que irradia efeitos por todo o ordenamento jurídico e da teoria dos direitos fundamentais edificados sobre o fundamento da dignidade da pessoa humana, a tendência jusfilosófica pós-positivista passou a oferecer ao Direito ferramentas mais compatíveis com os complexos problemas da plural 


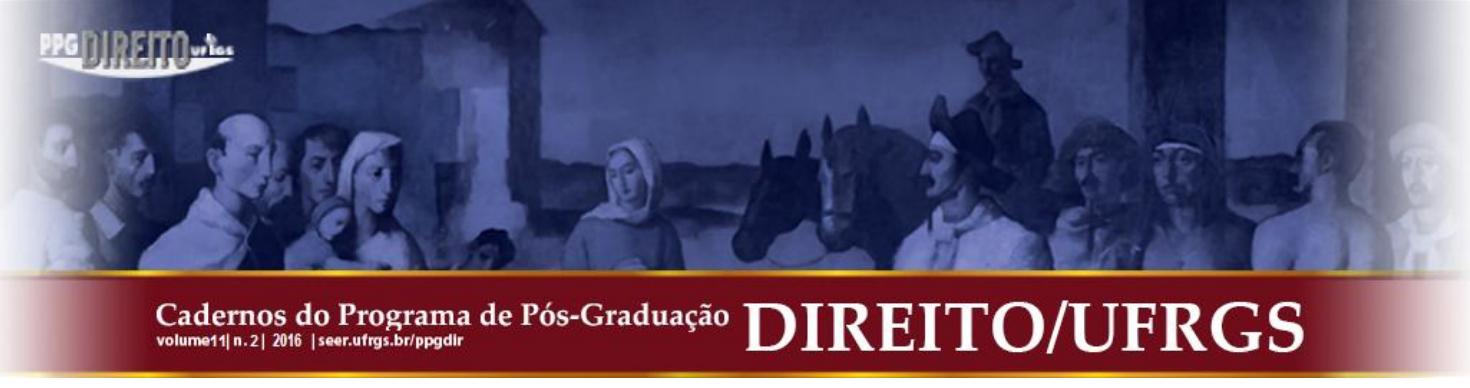

sociedade contemporânea, mediante a harmonização do plano da legalidade com o da legitimidade, de modo a firmar os laços éticos entre o universo jurídico e a moralidade social.

Essa tendência pós-positivista acaba por se apresentar ao Direito do Trabalho como verdadeira tábua de salvação diante da crise juslaboral a partir da década de 70 no Brasil. Era a solução para o momento paradoxal em que se encontrava o Direito do Trabalho, quando o direito tutelar pugnava por tutela diante das investidas neoliberais, que imputavam aos ombros do trabalhador a culpa pela crise socioeconômica do período.

O Direito do Trabalho pós-positivista passa a exigir uma nova postura do intérprete do Direito, que, diferentemente do antigo mote positivista "interpretar para compreender", inverte-se agora à "compreensão para interpretar" ${ }^{38}$. Impõe à toda a atividade jurídica e política do Estado e até mesmo dos particulares a compreensão de que as relações trabalhistas se inserem no contexto de centralidade das normas constitucionais.

É dizer, o paradigma pós-positivista trabalhista, ao transformar os princípios e valores do trabalho em parte integrante do núcleo constitucional irradiador de efeitos para toda a ordem jurídica, oferece especial ênfase à valorização do trabalho humano e, assim, apresentase como instrumento essencial para a realização do projeto constitucional de afirmação da dignidade da pessoa humana, de democratização da tutela social e de alcance da justiça social.

Diante do contexto pós-positivista e tendo em vista a rica atenção dada pela já quase trintenária Carta Cidadã de 1988 às normas trabalhistas, podemos então nos assegurar - e porque não nos vangloriar - da existência de uma maturidade de organização política e jusfilosófica capaz de proteger o Direito do Trabalho contra qualquer nova investida.

Possivelmente a repaginação do Direito do Trabalho pela visão pós-positivista não seja a única e exata solução para os grandes desafios constitucionais democráticos do século XXI; porém, certamente se mostra como um promissor caminho a se tomar, ou, no mínimo, um grande motivador do caminhar.

\footnotetext{
${ }^{58}$ STRECK, Lenio Luiz. A hermenêutica e as possibilidades de superação do positivismo pelo (neo)constitucionalismo. In: ROCHA, Leonel Severo; STRECK, Lenio Luiz (Org.). Constituição, sistemas sociais e hermenêutica. Porto Alegre: Livraria do Advogado, 2005. p. 159.
} 


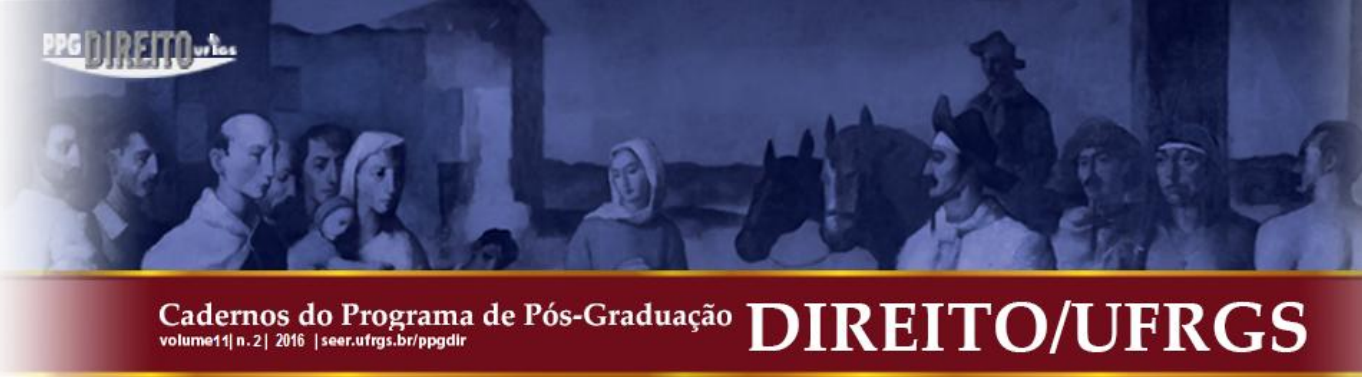

HART, Herbert Lionel Adolphus. O Conceito de Direito. $3^{\text {a }}$ edição. Tradução de A. Ribeiro Mendes. Lisboa: Fundação Calouste Gulbekian, 1994.

KELSEN, Hans. Teoria pura do Direito. Tradução de João Baptista Machado. $6^{\text {a }}$ ed. São Paulo: Martins Fontes, 1999.

LARENZ, Karl. Metodologia da Ciência do Direito. Tradução de José Lamego. $3^{\text {a }}$ ed. Lisboa: Fundação Calouste Gulbenkian, 1997.

MENDES, Gilmar Ferreira; BRANCO, Paulo Gustavo Gonet. Curso de direito constitucional. $9^{\mathrm{a}}$ ed. São Paulo: Saraiva. 2014.

REALE, Miguel. Lições preliminares de Direito. 27ª ed. São Paulo: Saraiva, 2004.

SANCHÍS, Luis Prieto. Del mito a la decadencia de la Ley: la Ley en el estado constitucional. In: Ley, principios, derechos. Madrid: Dykinson, 1998. p. 5-45

Sobre el neoconstitucionalismo y sus implicaciones. In: Justicia Constitucional y Derechos Fundamentales. Madrid: Trotta, 2003.

SARLET, Ingo Wolfgang. A eficácia dos direitos fundamentais. $11^{\mathrm{a}}$ edição. Porto Alegre: Livraria do advogado, 2012. E-book. ISBN 978-85-7348-789-3. p. 53.

SARMENTO, Daniel Os direitos fundamentais nos paradigmas liberal, social e pós-social (Pós-Modernidade Constitucional?). In: SAMPAIO, José Adércio Leite (Coord.). Crise e desafios da Constituição: perspectivas críticas da teoria e das práticas constitucionais brasileiras. Belo Horizonte: Del Rey, 2003.

SILVA, José Afonso da. Curso de Direito Constitucional positivo. São Paulo: Malheiros, 2002.

STRECK, Lenio Luiz. A hermenêutica e as possibilidades de superação do positivismo pelo (neo)constitucionalismo. In: ROCHA, Leonel Severo; STRECK, Lenio Luiz (Org.). Constituição, sistemas sociais e hermenêutica. Porto Alegre: Livraria do Advogado, 2005. p. 153-185. 


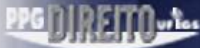 \\ Cadernos do Programa de Pós-Graduação volume11| n.2| 2016 | seer.utrgs.br/ppgdl

STRECK, Lenio Luiz; MORAIS, José Luis Bolzan de. Ciência política e teoria geral do estado. $3^{\mathrm{a}}$ ed. Porto Alegre: Livraria do Advogado, 2003.

Submissão: 21/01/2016

Aceito para Publicação: 29/04/2016 


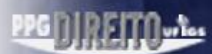

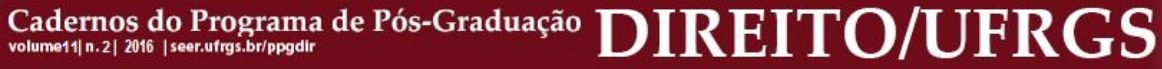

342 